\title{
Pollution transport from North America to Greenland during summer 2008
}

\author{
J. L. Thomas ${ }^{1}$, J.-C. Raut $^{1}$, K. S. Law ${ }^{1}$, L. Marelle ${ }^{1}$, G. Ancellet ${ }^{1}$, F. Ravetta ${ }^{1}$, J. D. Fast ${ }^{2}$, G. Pfister ${ }^{3}$, L. K. Emmons ${ }^{3}$, \\ G. S. Diskin ${ }^{4}$, A. Weinheimer ${ }^{3}$, A. Roiger ${ }^{5}$, and H. Schlager ${ }^{5}$ \\ ${ }^{1}$ UPMC Univ. Paris 06, Université Versailles St-Quentin, CNRS/INSU, UMR8190, LATMOS-IPSL, Paris, France \\ ${ }^{2}$ Pacific Northwest National Laboratory, Richland, WA, USA \\ ${ }^{3}$ National Center for Atmospheric Research, Boulder, CO, USA \\ ${ }^{4}$ NASA Langley Research Center, Hampton, VA, USA \\ ${ }^{5}$ Institut für Physik der Atmosphäre, Deutsches Zentrum für Luft- und Raumfahrt (DLR), Oberpfaffenhofen, Germany
}

Correspondence to: J. L. Thomas (jennie.thomas@latmos.ipsl.fr)

Received: 17 October 2012 - Published in Atmos. Chem. Phys. Discuss.: 20 November 2012

Revised: 1 March 2013 - Accepted: 6 March 2013 - Published: 10 April 2013

\begin{abstract}
Ozone pollution transported to the Arctic is a significant concern because of the rapid, enhanced warming in high northern latitudes, which is caused, in part, by shortlived climate forcers, such as ozone. Long-range transport of pollution contributes to background and episodic ozone levels in the Arctic. However, the extent to which plumes are photochemically active during transport, particularly during the summer, is still uncertain. In this study, regional chemical transport model simulations are used to examine photochemical production of ozone in air masses originating from boreal fire and anthropogenic emissions over North America and during their transport toward the Arctic during early July 2008. Model results are evaluated using POLARCAT aircraft data collected over boreal fire source regions in Canada (ARCTAS-B) and several days downwind over Greenland (POLARCAT-France and POLARCAT-GRACE). Model results are generally in good agreement with the observations, except for certain trace gas species over boreal fire regions, in some cases indicating that the fire emissions are too low. Anthropogenic and biomass burning pollution (BB) from North America was rapidly uplifted during transport east and north to Greenland where pollution plumes were observed in the mid- and upper troposphere during POLARCAT. A model sensitivity study shows that $\mathrm{CO}$ levels are in better agreement with POLARCAT measurements (fresh and aged fire plumes) upon doubling $\mathrm{CO}$ emissions from fires. Analysis of model results, using $\Delta \mathrm{O}_{3} / \Delta \mathrm{CO}$ enhancement ratios, shows that pollution plumes formed ozone dur-
\end{abstract}

ing transport towards the Arctic. Fresh anthropogenic plumes have average $\Delta \mathrm{O}_{3} / \Delta \mathrm{CO}$ enhancement ratios of 0.63 increasing to 0.92 for aged anthropogenic plumes, indicating additional ozone production during aging. Fresh fire plumes are only slightly enhanced in ozone $\left(\Delta \mathrm{O}_{3} / \Delta \mathrm{CO}=0.08\right)$, but form ozone downwind with $\Delta \mathrm{O}_{3} / \Delta \mathrm{CO}$ of 0.49 for aged $\mathrm{BB}$ plumes (model-based run). We estimate that aged anthropogenic and BB pollution together made an important contribution to ozone levels with an average contribution for latitudes $>55^{\circ} \mathrm{N}$ of up to $6.5 \mathrm{ppbv}(18 \%)$ from anthropogenic pollution and 3 ppbv (5.2\%) from fire pollution in the model domain in summer 2008.

\section{Introduction}

Understanding atmospheric composition and its connection to warming in the Arctic is essential because of the rapid speed at which the region is already experiencing change, such as decreasing summer sea-ice ice extent and impacts on ecosystems (e.g. Arctic Climate Impact Assessment, 2004; Anisimov et al., 2007; Comiso et al., 2008; Post et al., 2009). It is clear that long-lived greenhouse gases (principally $\mathrm{CO}_{2}$ ) have contributed to Arctic warming (IPCC, 2007). However, the contribution of trace gases and aerosols, which act as short-lived climate forcers (SLCFs) by either cooling or warming the atmosphere, is less certain. It has been suggested that SLCFs that warm the atmosphere, notably ozone 
$\left(\mathrm{O}_{3}\right)$, black carbon $(\mathrm{BC})$, and methane $\left(\mathrm{CH}_{4}\right)$, contribute nearly as much as $\mathrm{CO}_{2}$ to Arctic warming (e.g. Quinn et al., 2008; Koch et al., 2011), and reductions could reduce the rate of Arctic warming in the 20-50 yrs timeframe (WMO/UNEP, 2011). On the other hand, the main impact of SLCFs over the last century has been a net cooling, primarily due to rising sulfur emissions producing sulfate aerosols, which has offset global warming (IPCC, 2007). However, recent reductions in sulfur emissions over Eurasia and North America have likely resulted in less cooling and additional warming (Koch et al., 2011).

In this paper, we focus on tropospheric ozone, which has increased significantly over the last $20-30$ yrs in the Northern Hemisphere (e.g. Parrish et al., 2012), and where better understanding is needed about its contribution to Arctic climate change. Shindell (2007) showed that Arctic ozone radiative forcing is divided almost equally between ozone produced at mid-latitudes and forcing from ozone produced during transport and within the Arctic. Ozone is also a pollutant, which is harmful to humans and vegetation/crops. It is formed via photochemistry involving ozone precursor emissions including $\mathrm{NO}_{\mathrm{x}}\left(\mathrm{NO}+\mathrm{NO}_{2}\right)$, and volatile organic compounds (and their products) from anthropogenic fossil fuel (FF) and biomass burning (BB). In the troposphere, ozone is destroyed by photolysis and reactions involving water vapor and hydroxyl radicals as well as dry deposition at the surface. Tropospheric ozone can be formed and then transported downwind from emission regions. It can also be formed after transport due to decomposition of peroxy-acetyl nitrate (PAN) in aged air masses. PAN releases $\mathrm{NO}_{\mathrm{x}}$ after descent to lower, warmer altitudes (e.g. Wild et al., 1996). The contribution of pollution to Arctic ozone, especially as a function of emission region and time of year, is still uncertain. Despite much progress in understanding ozone formation, destruction, and transport at mid-latitudes (summarized in HTAP, 2010), there have been fewer studies examining the origins of tropospheric ozone in the Arctic.

Earlier studies focused on Arctic ozone in the late winter/spring and ozone production during the spring equinox (TOPSE campaign) (e.g. Atlas et al., 2003) when there is a build up of Arctic Haze (Barrie et al., 1986) containing elevated pollution levels and maximum transport of ozone from the stratosphere (e.g. Emmons et al., 2003). In addition, there has been a focus on understanding observations at surface sites exhibiting very low ozone levels due to halogen chemistry (e.g. Bottenheim et al., 1990; Simpson et al., 2007; Abbatt et al., 2012). Less attention has been paid to Arctic-free tropospheric ozone in the summer months, the focus of this study, even though it is the time of year with maximum sunlight (resulting in rapid photochemistry) and maximum boreal forest fire emissions. In the late 1980s, the Arctic Boundary Layer Expeditions (ABLE) 3A and 3B made some of the first summertime airborne chemical trace gas measurements in the lower- and mid-troposphere $(<6 \mathrm{~km})$, looking at boreal fire and anthropogenic emission impacts on ozone (Jacob et al., 1992; Fan et al., 1994). The importance of PAN decomposition as a source of $\mathrm{NO}_{\mathrm{x}}$ at high latitudes was noted (Jacob et al., 1992) and Mauzerall et al. (1996) concluded that in situ production was the main source of ozone in the lower-/mid-troposphere at high latitudes with an increasing stratospheric contribution with altitude. More recently, Walker et al. (2012), using a global chemistry transport model, also found PAN decomposition to be an important source of $\mathrm{NO}_{\mathrm{x}}$ and ozone north of $60^{\circ} \mathrm{N}$. During ABLE, ozone production from $\mathrm{BB}$ was found to be negligible over the study regions (eastern Canada, western Alaska) due to low $\mathrm{NO}_{\mathrm{X}} / \mathrm{CO}$ emission ratios in fires and rapid conversion of $\mathrm{NO}_{\mathrm{x}}$ to PAN (Jacob et al., 1992; Mauzerall et al., 1996) although subsequent studies have found significant evidence for enhanced ozone in BB plumes downwind of fire regions at mid-latitudes (McKeen et al., 2002; Pfister et al., 2006; Real et al., 2007). It has also been shown that ozone production in BB plumes can be enhanced by mixing with other air masses, for example aged BB plumes that mix with urban emissions, which increases the ozone produced due to fires (e.g. McKeen et al., 2002; Singh et al., 2010). During ABLE 3A/3B, comparison of ozone enhancements relative to $\mathrm{CO}$ enhancements in $\mathrm{BB}$ and anthropogenic plumes showed lower ratios (0.04-0.18) in BB plumes compared to anthropogenic plumes observed over the eastern United States (0.30.5 ) even though the Canadian BB plumes sampled during the campaign were rather aged $(\mathrm{CO}<200 \mathrm{ppbv})$ (Wofsy et al., 1992). Boreal fires were also found to be a more important source of PAN and $\mathrm{NO}_{\mathrm{x}}$ (following PAN decomposition) than anthropogenic emissions (Fan et al., 1994).

While these earlier findings provided some new insights, they also provoked new questions about the impact of boreal fires on budgets of nitrogen species, oxygenated hydrocarbons and ozone (e.g. Law and Stohl, 2007). This, together with significant advances in measurement techniques and numerical modeling, inspired the International Polar Year (IPY) activity POLARCAT (Polar Study using Aircraft, Remote Sensing, Surface Measurements and Models, of Climate, Chemistry, Aerosols, and Transport). POLARCAT consisted of multiple coordinated aircraft campaigns including NASA ARCTAS (Arctic Research of the Composition of the Troposphere from Aircraft and Satellites) and POLARCAT-France/POLARCAT-GRACE (GReenland Aerosol and Chemistry Experiment) in spring and summer 2008 (Jacob et al., 2010; Schmale et al., 2011; Roiger et al., 2011b; Pommier et al., 2012).

Studies based on the analysis of ARCTAS-B data have concluded that boreal fire emissions had little impact on ozone during June-July 2008 (Alvarado et al., 2010; Wespes et al., 2012; Singh et al., 2010). A constrained box modeling study, based on the same data, estimated high in situ net photochemical production rates, particularly in the lower troposphere, but little or no enhancements in measured ozone were found in analyzed BB plumes (Olson et al., 2012). However, these plumes were mainly sampled very near or $1-2$ 
days downwind from fires. The contribution of Asian anthropogenic emissions was found to be important for summertime Arctic CO (Bian et al., 2012) and ozone (Wespes et al., 2012). However, according to Wespes et al. (2012), North American emissions only made a very small contribution to ozone north of $60^{\circ} \mathrm{N}$.

Global three-dimensional (3-D) chemistry transport models (CTMs) have been used to interpret summer POLARCAT data (primarily ARCTAS-B), although models have shown discrepancies when compared to aircraft data, including underestimation of ozone and $\mathrm{CO}$ in the mid-troposphere (Alvarado et al., 2010; Wespes et al., 2012; Bian et al., 2012). Previously, global models were also shown to underestimate ozone and $\mathrm{CO}$ in the remote Arctic during summer, for example at Summit in central Greenland, a receptor region for mid-latitudes pollution (Shindell et al., 2008). Alvarado et al. (2010) suggested there is little ozone production in young fire plumes by comparing a global model run without fire emissions with a base model run including fires with ARCTAS-B data. In their study, underestimation of ozone above $3 \mathrm{~km}$ was attributed to underprediction of stratosphere-troposphere exchange in the model, underrepresentation of ozone transported from mid-latitudes, or errors in ozone production in smoke plumes. However, coarse model resolutions may also be influencing results (Wespes et al., 2012) and the resulting ozone concentrations.

We use POLARCAT data combined with a high-resolution CTM (WRF-Chem) to understand photochemical ozone production in plumes originating from Canadian BB and North American anthropogenic pollution during summer 2008. We focus on a period when multiple aircraft were flying in different regions (N. America and Greenland) with the specific aim of studying pollution during transport to the Arctic. The methodology used for this study is described in Sect. 2. In Sect. 3, we evaluate the representation of plumes in the model over Canada and the northeastern United States. In addition, the representation of plumes after long-range transport over Greenland is studied. In Sect. 4, we focus on two specific plumes as examples of pollution plumes transported towards the Arctic during summer 2008 and use the Lagrangian model FLEXPART to examine plume origin. In Sect. 5, we investigate ozone production close to and downwind of emission regions using emission sensitivity studies. Model results are used to estimate the amount of ozone transported towards the Arctic during the study period. Finally, conclusions are presented in Sect. 6.

\section{Methods}

\subsection{Model calculations}

Regional CTM simulations were performed using the Weather Research and Forecasting model including gas and aerosol chemistry (WRF-Chem Version 3.3) (Grell et al.,
2005; Fast et al., 2006). The model was run from 28 June 2008 to 9 July 2008 using a polar-stereographic grid $(35 \times$ $35 \mathrm{~km}$ resolution) over a domain encompassing boreal fires and anthropogenic emission regions and downwind over Greenland (see Fig. 1). The model was run with 27 vertical levels from the surface to $50 \mathrm{hPa}$. Initial meteorological and boundary conditions were taken from the NCEP (National Center for Environmental Prediction)-Global Forecasting System (GFS) with nudging applied to wind, temperature, and humidity every $6 \mathrm{~h}$. Spatially and temporally (6-hourly) varying chemical boundary conditions were provided by global model simulations from the Model for OZone and related Chemical Tracers (MOZART-4) (Emmons et al., 2010), run at $1.9^{\circ}$ (lat) $\times 2.5^{\circ}$ (lon) and forced with NASA GEOS-5 analyses. In WRF-Chem, similar to the global MOZART-4 model, the mixing ratios of selected chemical species (e.g. $\mathrm{O}_{3}, \mathrm{~N}_{2} \mathrm{O}, \mathrm{HNO}_{3}$, etc.) are set to climatological values above $50 \mathrm{hPa}$, and relaxed to a climatology down to the tropopause. For consistency, both WRF-Chem and MOZART-4 employed the MOZART-4 gas-phase chemical scheme described in Emmons et al. (2010). MOZART4 includes a bulk aerosol scheme, whereas in WRF-Chem MOZART-4 gas phase chemistry is linked to the bulk aerosol scheme GOCART (Goddard Chemistry Aerosol Radiation and Transport model, Chin et al., 2002), referred to as MOZCART.

All model runs (global and regional) were based on the same emissions. The anthropogenic emission inventory developed for NASA ARCTAS by D. Streets and Q. Zhang (http://www.cgrer.uiowa.edu/arctas/emission. html) was used. Fire emissions were included using the Fire INventory from NCAR (FINNv1) (Wiedinmyer et al., 2006, 2011), with a diurnal profile as described in Pfister et al. (2011). Fire emissions in MOZART-4 were released in the lowest model level, while in WRF-Chem an online plume rise module (Freitas et al., 2007) was used to distribute the fire emissions vertically. This scheme was recently shown to perform well for the fires observed during ARCTAS (Sessions et al., 2011). Biogenic emissions were from Model of Emissions of Gases and Aerosols from Nature (MEGAN) (Guenther et al., 2006). Three WRF-Chem model runs were performed: a base run with all emissions included; a run without fire emissions (noFire run); and a run without anthropogenic emissions (noAnthro run). In the latter 2 cases, the respective emissions (fire or anthropogenic) were switched off for the duration of the run inside the regional model domain. Two additional sensitivity runs have been completed to further investigate chemistry in fire plumes: a run with double fire $\mathrm{CO}$ emissions (FireCOSens) and a run with half of the fire $\mathrm{NO}_{\mathrm{x}}$ emissions (FireNOxSens). All model runs used the same MOZART boundary conditions, therefore the sensitivity runs highlight changes due to emissions within the model domain (Canadian fires and northeastern US anthropogenic emissions). 
Table 1. POLARCAT flights included for analysis.

\begin{tabular}{lll}
\hline Campaign & Aircraft & Dates included for analysis \\
\hline ARCTAS-B & DC8 & 29 Jun ${ }^{\mathrm{a}}$, 1 Jul, 4 Jul, 5 Jul \\
POLARCAT-France & ATR-42 & 5 Jul, 7 Jul, 8 Jul \\
POLARCAT-GRACE & Falcon-20 & 4 Jul, 7 Jul, 8 Jul \\
MOZAIC & Commercial Aircraft & 3 Jul \\
\hline
\end{tabular}

a Only data within the WRF-Chem domain included for analysis.

b Two vertical profiles taken during takeoff or landing from Philadelphia $\left(40.0^{\circ} \mathrm{N}, 75.2^{\circ} \mathrm{W}\right)$.

We also use FLEXPART (Stohl et al., 2005), a Lagrangian model that simulates transport and dispersion of air parcels within the troposphere, which can be used to evaluate air mass origins. Fast and Easter (2006) modified version 6.2 of FLEXPART to use mesoscale meteorological data from WRF as input, referred to as FLEXPART-WRF (also described in Peffers et al., 2009). FLEXPART-WRF is used in backward configuration to determine the origin of plumes transported to the Arctic.

\subsection{POLARCAT summer measurement campaigns}

The summer POLARCAT campaigns were dedicated, in part, to the study of boreal forest fires and their impact on Arctic chemical composition. Another focus was to examine pollution transported to the Arctic, including the chemical evolution of anthropogenic plumes. A summary of all the POLARCAT flights used in our study is shown in Table 1 . We use data from the DC8 deployment as part of ARCTAS-B over Canada, including flights from 29 June to 5 July 2008 (Jacob et al., 2010). The main focus of these flights included detailed characterization of fresh Saskatchewan fire plumes. Aged fire plumes from Siberia and California were also targeted during this period. The DC8 was equipped with a suite of instruments to characterize atmospheric composition. $\mathrm{CO}$ was measured using the well-characterized DACOM tunable diode laser absorption spectrometer, with a nominal time resolution of $\sim 1 \mathrm{~s}$, precision $(1 \sigma)$ of $<1 \%$, and an accuracy (referenced to NOAA standards) of $2 \%$ (Vay et al., 1998; Sachse et al., 1987). Ozone was measured via its chemiluminescent reaction with reagent NO that was added to the sample flow airstream to generate a photon-counting signal proportional to the ambient ozone mixing ratio, with $4 \%$ uncertainty (Weinheimer et al., 1994). In addition, we compare model results with $\mathrm{PAN}, \mathrm{NO}_{\mathrm{x}}$, and non-methane hydrocarbon (NMHC) measurements made onboard the DC8 as described in Jacob et al. (2010) and Hornbrook et al. (2011).

While not part of POLARCAT, we also use MOZAIC (Measurements of OZone and water vapour by in-service AIrbus airCraft) (Marenco et al., 1998) profiles to evaluate model results over the main anthropogenic source region in our study, focusing on two flights in and out of the northeastern United States on 3 July 2008. MOZAIC ozone measurements were made with a dual beam UV absorption in- strument (Thouret et al., 1998) which has a detection limit of 2 ppbv. CO measurements were performed using an infrared correlation instrument with a precision of $\pm(5 \mathrm{ppbv}+5 \%)$ (Nédélec et al., 2003). During POLARCAT-France, flights in the area of southern Greenland were conducted in July 2008 by the ATR-42 aircraft based in Kangerlussuaq, Greenland $\left(67.01^{\circ} \mathrm{N}, 50.7^{\circ} \mathrm{W}\right)$ with the aim of measuring aged pollution during transport to the Arctic (Schmale et al., 2011; Pommier et al., 2010). Measurements onboard included $\mathrm{O}_{3}$ and $\mathrm{CO}$ as well as ozone lidar profiles. $\mathrm{CO}$ was measured using IR absorption gas correlation with a modified commercial gas analyzer Thermo 48C (Thermo Environmental Instruments, USA) as described in Nédélec et al. (2003). The instrument is calibrated using a $\mathrm{CO}$ standard referenced from NIST (National Institute of Standards and Technology) with an accuracy of $\pm 1 \%$. The precision for a $30 \mathrm{~s}$ integration time is 5 ppbv and the detection limit is 10 ppbv. The $\mathrm{O}_{3}$ in situ measurements are made with a commercial fast response ozone analyzer (Model 49C TEI Thermo Environment Instruments, USA) which has been adapted for airborne operation. The precision is of the order of 2 ppbv for an integration time of $4 \mathrm{~s}$.

The lidar measurements of ozone through the upper troposphere lower stratosphere (UTLS) between 7-12 km were made using an airborne UV DIAL lidar on the ATR-42 aircraft during the POLARCAT-France summer campaign. The lidar was mounted to perform ozone upward-looking vertical profiles. The measurement range is of the order of $6 \mathrm{~km}$ above the aircraft altitude with $300 \mathrm{~m}$ vertical resolution and 2-5 min temporal resolution. The system is described in Ancellet and Ravetta (1998) and performance during various airborne applications is given in Ancellet and Ravetta (2003). Numerous comparisons have been conducted with in situ measurements (ECC ozonesonde of airborne UV photometer) showing an ozone accuracy better than $7 \%$ for clear air measurements. Only measurements between the aircraft and clouds or thick aerosol layers are shown, because ozone retrievals in/above such layers is not possible.

During the same period, the DLR Falcon-20 was based in Kangerlussuaq, Greenland, as part of the POLARCATGRACE campaign (Roiger et al., 2011b). Measurements included $\mathrm{O}_{3}, \mathrm{CO}, \mathrm{CO}_{2}, \mathrm{NO}, \mathrm{PAN}, \mathrm{NO}_{\mathrm{y}}$, and photolysis rates of $\mathrm{NO}_{2}$. $\mathrm{CO}$ was detected using vacuum ultraviolet 


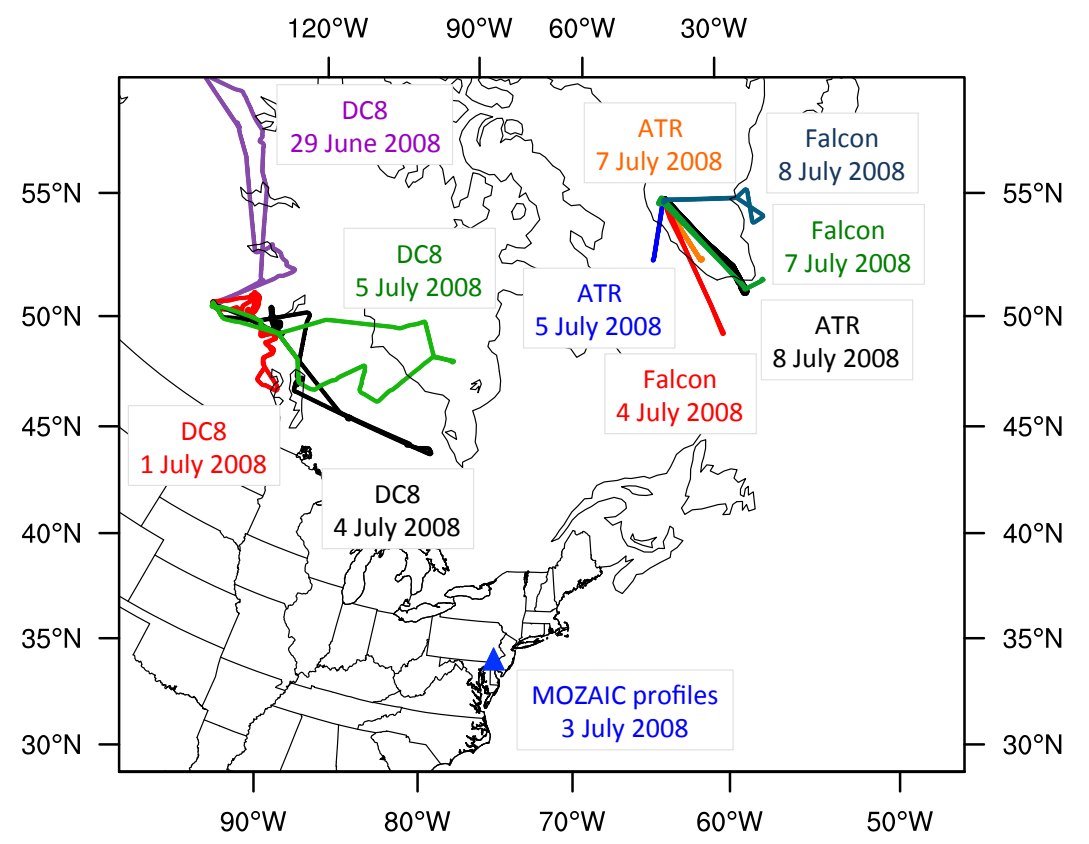

Fig. 1. Map of the WRF-Chem domain and the flights conducted as part of POLARCAT used to evaluate the model. The NASA DC8 flights are shown in purple (29 June), red (1 July), black (4 July) and green (5 July). The ATR-42 flights are shown in blue (5 July), orange (7 July), and black (8 July). The Falcon-20 flights are shown in red (4 July), green (7 July), and light blue (8 July). The location of the two MOZAIC profiles during flights in and out of Philadelphia, Pennsylvania on 3 July is shown by the blue triangle.

(UV) fluorescence (Gerbig et al., 1999; accuracy $\pm 5 \%$ ), and ozone by UV absorption (TEI49C, accuracy $\pm 5 \%$ ). NO and $\mathrm{NO}_{\mathrm{y}}$ (sum of all reactive nitrogen species) were measured using a chemiluminescence detector (Ziereis et al., 2000, accuracy $\pm 10-15 \%) . \mathrm{NO}_{\mathrm{y}}\left(\mathrm{NO}_{\mathrm{y}}=\mathrm{NO}_{\mathrm{x}}, \mathrm{HNO}_{3}, \mathrm{~N}_{2} \mathrm{O}_{5}, \mathrm{PAN}\right.$, and other reactive nitrogen species) was converted to $\mathrm{NO}$ using a heated gold converter with added $\mathrm{CO}$ and then detected. PAN was measured using a chemical ionization-ion trap mass spectrometer with a time resolution of $2 \mathrm{~s}$ and an accuracy of $\pm 10 \%$ (Roiger et al., 2011a).

\section{Model evaluation}

In order to evaluate the model results, output from WRFChem has been compared with aircraft data collected during POLARCAT. We focus on the ARCTAS-B flights over fresh Canadian forest fires, between 29 June and 5 July 2008. These fresh fire plumes were measured downwind (typical transport time 5-7 days) between 4 July and 8 July by the French and German aircraft. Therefore, we focus on flights over southern Greenland several days after emissions were measured by the DC8 (three ATR-42 flights and three Falcon-20 flights). Because there were no specific campaign flights over the northeastern United States, the main anthropogenic source region in our study, we use MOZAIC data collected during flights in and out of Philadelphia to evaluate the model in this region. A summary of all of the flights used in the analysis is given in Table 1 and flights are shown in Fig. 1.

The observation period and model run include intense boreal forest fires over Canada that were sampled by the DC8, and elevated summertime pollution over the northeast United States. Plumes from these sources were rapidly uplifted and transported in warm conveyor belts linked to the development of a series of frontal systems (Fuelberg et al., 2010). Many of the plumes were transported east and north towards the Arctic during this period. Figure 2 shows examples of modeled plumes at altitudes of 1 and $2 \mathrm{~km}$ (indicated by $\mathrm{CO}$ mixing ratios $>100 \mathrm{ppbv}$ ) over the fire and anthropogenic source regions in early July (Fig. 2a-c) that were transported towards the Arctic and sampled later downwind by the French and German aircraft at 4, 7, and 8 km (Fig. 2d-f). To compare the model results with the observations, hourly model output data have been averaged in the region of the aircraft (using $3 \times 3$ grid cells in the horizontal and 3 vertical layers) and interpolated in time using analysis software from the Aerosol Modeling Testbed (Fast et al., 2011). These results are used to construct vertical profiles using $500 \mathrm{~m}$ bins.

There are a number of challenges when comparing highresolution model results and measurements, including both the temporal and spatial representation of plumes. Once emitted, pollution plumes undergo chemistry during longrange transport towards the Arctic. To evaluate the model representation of transport processes, model meteorology was compared with measurements of temperature, wind 

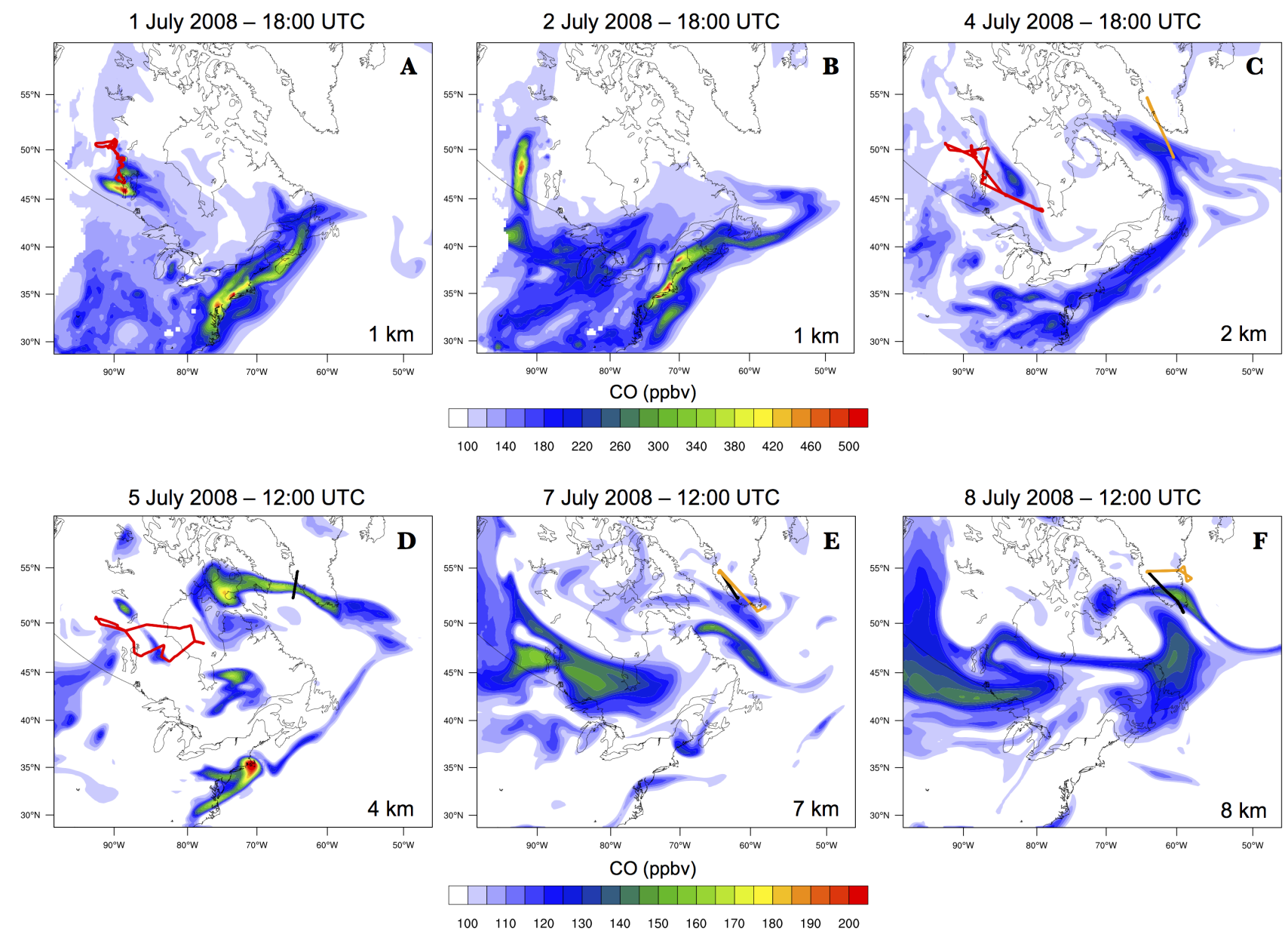

Fig. 2. Maps of pollution plumes, as indicated by model-predicted CO concentrations above 100 ppbv, between 1 July and 8 July. DC8 flight tracks are shown in red, ATR-42 flight tracks are shown in black, and Falcon-20 flight tracks are shown in orange.

speed, wind direction, and pressure. Results are shown in the online supplement (Figs. S1-S3). The overall good agreement between the model and measurements suggests that transport is represented correctly in the model. A number of issues (resolution of plumes, imperfect representation of long-range transport, non-linear chemistry, temporal and spatial resolution of emissions) make modeling long-range transport of pollution plumes particularly challenging. However, because of the nature of the POLARCAT campaigns, we have a unique dataset with both upwind and downwind measurements, which allows us to evaluate the model representation of plumes and their chemical evolution.

\subsection{Pollution source regions}

We compare vertical profiles from model results extracted along flight tracks for the model for the base, noAnthro, and noFire runs with the DC8 measurements in Fig. 3 for CO, ozone, $\mathrm{PAN}, \mathrm{NO}_{\mathrm{x}}$, ethane, ethene, and acetone (both obser- vations and model results were binned by altitude to construct profiles) for the flights over Canada in June and July 2008. For completeness, we also present, in the online supplement, model results along the flight tracks and in situ measurements for individual flights used in this study (Figs. S4S6). In general, the model results agree better with the measured values of $\mathrm{CO}$ and ozone with fires (base) than without fires (noFire). There is minimal influence from anthropogenic emissions in the region where the DC8 flew (noAnthro) due to the lack of anthropogenic emissions co-located with the fires. The base run underpredicts $\mathrm{CO}$ concentrations in fresh fire plumes (below $3 \mathrm{~km}$ ) by $50 \mathrm{ppbv}$, but this is within one standard deviation of the measurements. This likely indicates an underestimate in emissions from boreal forest fires in the FINNv1 emissions inventory. The underestimate of $\mathrm{CO}$ by the model is in part a result of the MOZART boundary conditions, as noted by Tilmes et al. (2011). The run with fire $\mathrm{CO}$ emissions increased by a factor of two (FireCOSens) more accurately represents $\mathrm{CO}$ measurements 

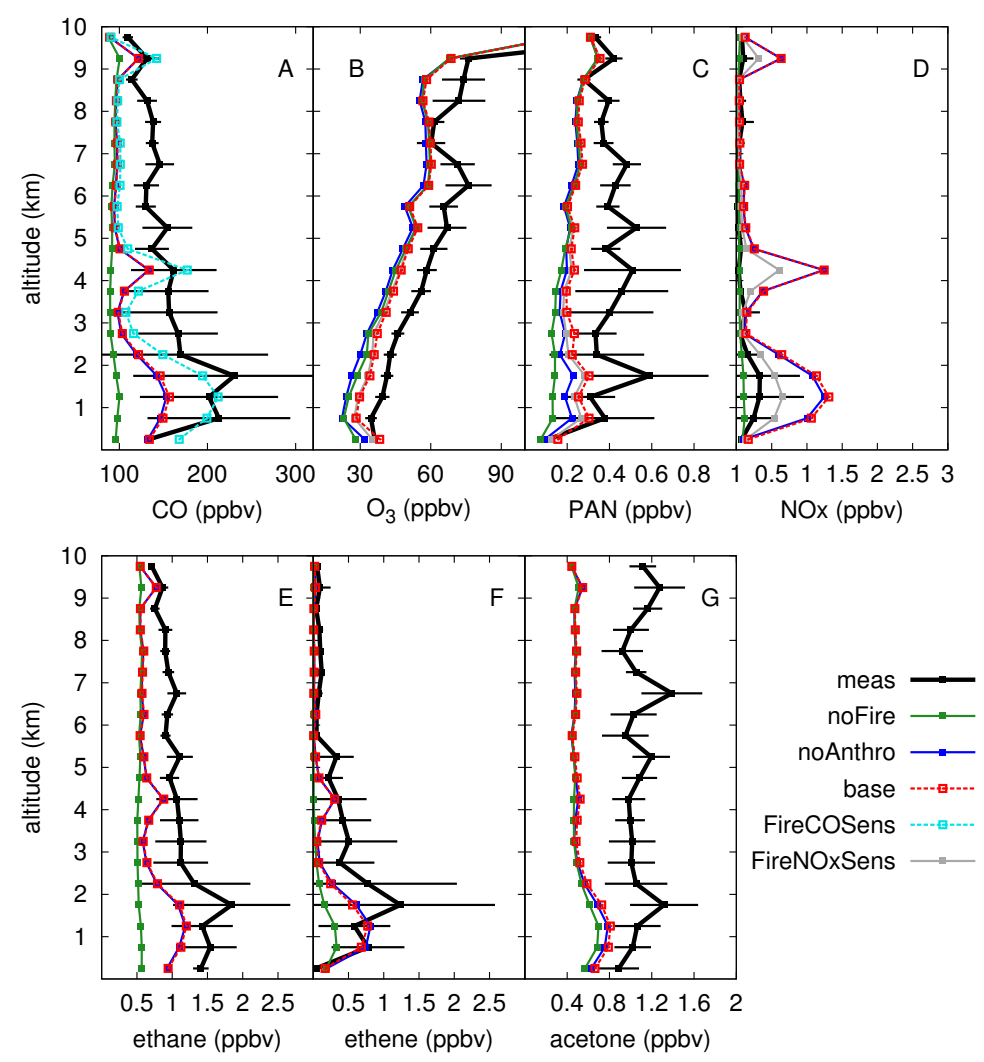

Fig. 3. Vertical profiles (averaged along flight tracks) for $\mathrm{CO}$, ozone, $\mathrm{PAN}, \mathrm{NO}_{\mathrm{x}}$, ethane, ethene, and acetone for the ARCTAS-B flights over Canada compared to WRF-Chem results - measurements are in black, the model base run is in red, the noFire run is in green, and the noAnthro run is in blue. Two fire emissions sensitivity runs are shown, the FireCOSens run is shown in teal (CO plot only) and the FireNOxSens run is shown in the ozone, PAN, and $\mathrm{NO}_{\mathrm{x}}$ plots in gray. The points indicate mean values every $500 \mathrm{~m}$ and the error bars show the standard deviation for the measurements. The flights included for the comparison over the fire source region are the DC8 flights on 29 June and on 1, 4, and 5 July. See text for details.

below $3 \mathrm{~km}$ by the DC8 flights than the base run (Fig. 3a). Above $3 \mathrm{~km} \mathrm{CO}$ is also too low compared to the measurements, indicating a low bias in CO from the MOZART-4 run used for both initial and boundary conditions (Fig. S7a).

Modeled ozone shows a low bias (5 ppbv) throughout the troposphere (Fig. 3b). The WRF-Chem profiles show only a small ozone sensitivity to removing fire emissions (noFire run), although there is an influence of fires on ozone concentrations in certain individual plumes (Fig. S4). Ozone values change very little in the FireCOSens run compared to the base run (not shown). Our findings for fresh fire plumes, using a high-resolution model, are consistent with the earlier study of Alvarado et al. (2010), which indicated that fire emissions had a minimal influence on ozone during flights close to the fire emissions. In their study, Alvarado et al. (2010) used the global model GEOS-Chem to investigate the behavior of fresh fire plumes during ARCTAS-B, focusing on all of the DC8 data. It is also important to note that while many of the DC8 sorties targeted plumes, the aircraft also made a large number of measurements in unpolluted air masses, which may limit the ability to discern the influence of fires on ozone production in individual plumes using campaign average vertical profiles. Ozone is biased low in the mid- and upper troposphere in our study, which originates from ozone concentrations in the MOZART-4 initial conditions (Fig. S7b) as noted by Wespes et al. (2012).

Fires emit nitrogen primarily as NO (Lobert and Warnatz, 1993; Andreae and Merlet, 2001), then photochemistry determines the relative amount of $\mathrm{NO}, \mathrm{NO}_{2}, \mathrm{HNO}_{3}, \mathrm{PAN}$, and other $\mathrm{NO}_{\mathrm{y}}$ species. PAN acts as a $\mathrm{NO}_{\mathrm{x}}$ reservoir, which can liberate $\mathrm{NO}_{\mathrm{x}}$ later and produce additional ozone in aged smoke plumes. We evaluate the modeled $\mathrm{NO}_{\mathrm{x}}$ and PAN in order to assess simulated ozone production in fires, which is limited by the amount of nitrogen available for photochemistry. In fresh fire plumes PAN concentrations are generally lower in the model than measured (Fig. 3c), indicating the $\mathrm{NO}_{\mathrm{x}}$ to PAN conversion is occurring more rapidly than captured by the model. In addition, $\mathrm{NO}_{\mathrm{x}}$ concentrations are too high in the base run below $5 \mathrm{~km}$. Alvarado et al. (2010) investigated the behavior of $\mathrm{NO}_{\mathrm{x}}$ and PAN in fire plumes during ARCTAS-B using the Fire Locating and Monitoring of Burning Emissions (FLAMBE) inventory (Reid et al., 2009). 

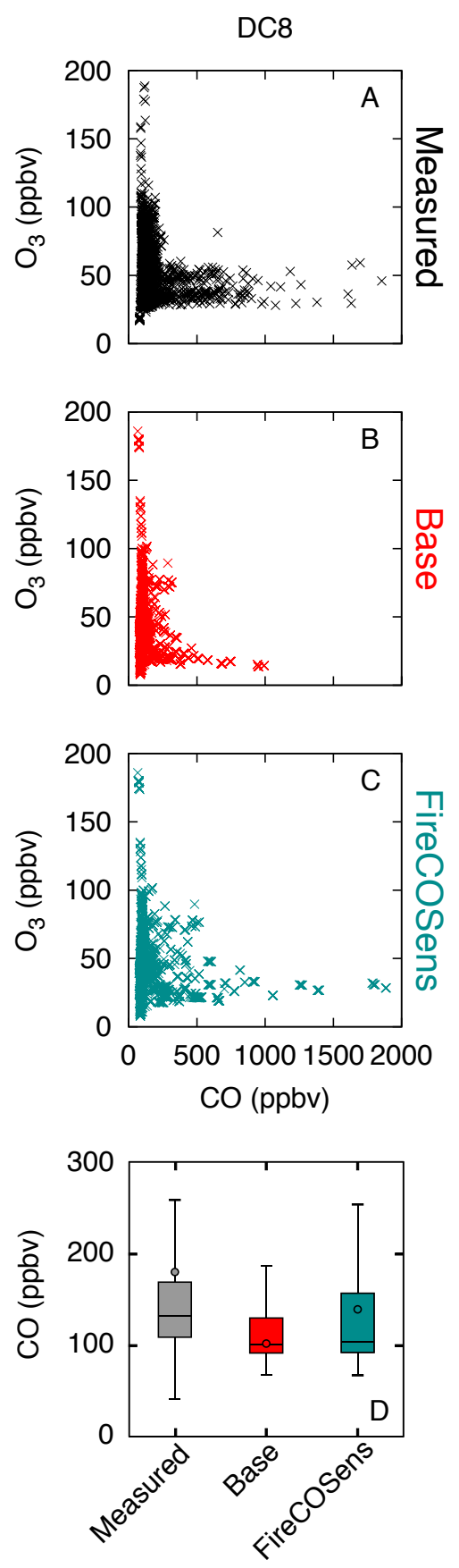

Fig. 4. Ozone versus CO correlations for the DC8 data (a), model base run (b), and a model run with $\mathrm{CO}$ emissions from fires $\mathrm{x} 2$, FireCOSens (c) for 29 June, 1, 4 and 5 July 2008. For comparison, model results are extracted along the DC8 flight tracks. Box and whisker plots for $\mathrm{CO}$ (measurements, model base run, and FireCOSens run) are shown in panel (d). For these plots, the box indicates the $25 \%$ and $75 \%$ percentiles, the line represents the median, and the circle shows the mean. In the measured data, very high values of $\mathrm{CO}$ measured in fires results in a mean value above the $75 \%$ percentile.

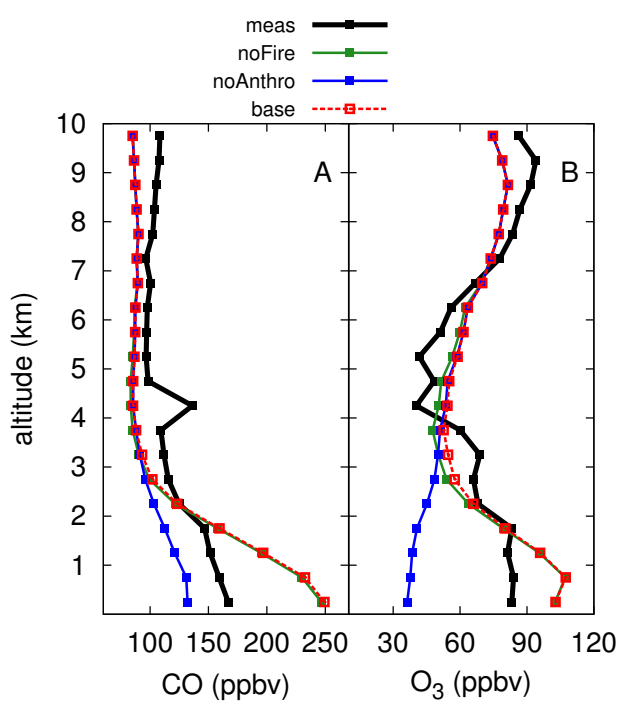

Fig. 5. Vertical profiles for MOZAIC flights over the northeastern United States compared to WRF-Chem results - measurements are in black, the model base run is in red, the noFire run is in green, and the noAnthro run is in blue. The comparison includes measurements onboard two commercial flights on 3 July.

Their study resulted in similar modeled $\mathrm{NO}_{\mathrm{x}}$ profiles, with overestimation of $\mathrm{NO}_{\mathrm{x}}$ in their base model run. The overprediction in $\mathrm{NO}_{\mathrm{x}}$ in part originates from the relatively limited data on which fire emissions inventories are built (see for example Wiedinmyer et al., 2011). A model sensitivity run with half of the $\mathrm{NO}_{\mathrm{x}}$ emissions improves the overall representation of $\mathrm{NO}_{\mathrm{x}}$ in fire plumes (Fig. 3d), but has a less significant impact on ozone and PAN formation in fresh fire plumes.

NMHCs concentrations in biomass burning plumes are also important for ozone production and are an important indicator of plume age. The NMHC levels also determine the rate of organic nitrate formation (for example PAN) and if reaction with organics is favored over conversion to nitric acid. Hornbrook et al. (2011) studied in detail the evolution of NMHCs during ARCTAS using measurements and box modeling. We show selected NMHCs (Fig. 3e-h) to evaluate the representation of modeled NMHCs in fresh fire plumes in WRF-Chem. We show ethane, ethene, and acetone to illustrate a range of important NMHCs in fire plumes. Modeled ethane and ethene are within the standard deviation of the measurements below $3 \mathrm{~km}$, suggesting that FINNv1 captures emissions of these species reasonably well. Acetone levels are, in general, too low in the model. We note that the agreement between the model and measurements is better below $3 \mathrm{~km}$ where the majority of fresh fire emissions are injected. Therefore, comparison of the profiles from $0-3 \mathrm{~km}$ provides the best evaluation WRF-Chem performance for fresh fire plumes. It is also important to note that the deficiencies in the representation of NMHCs and other species in models is 


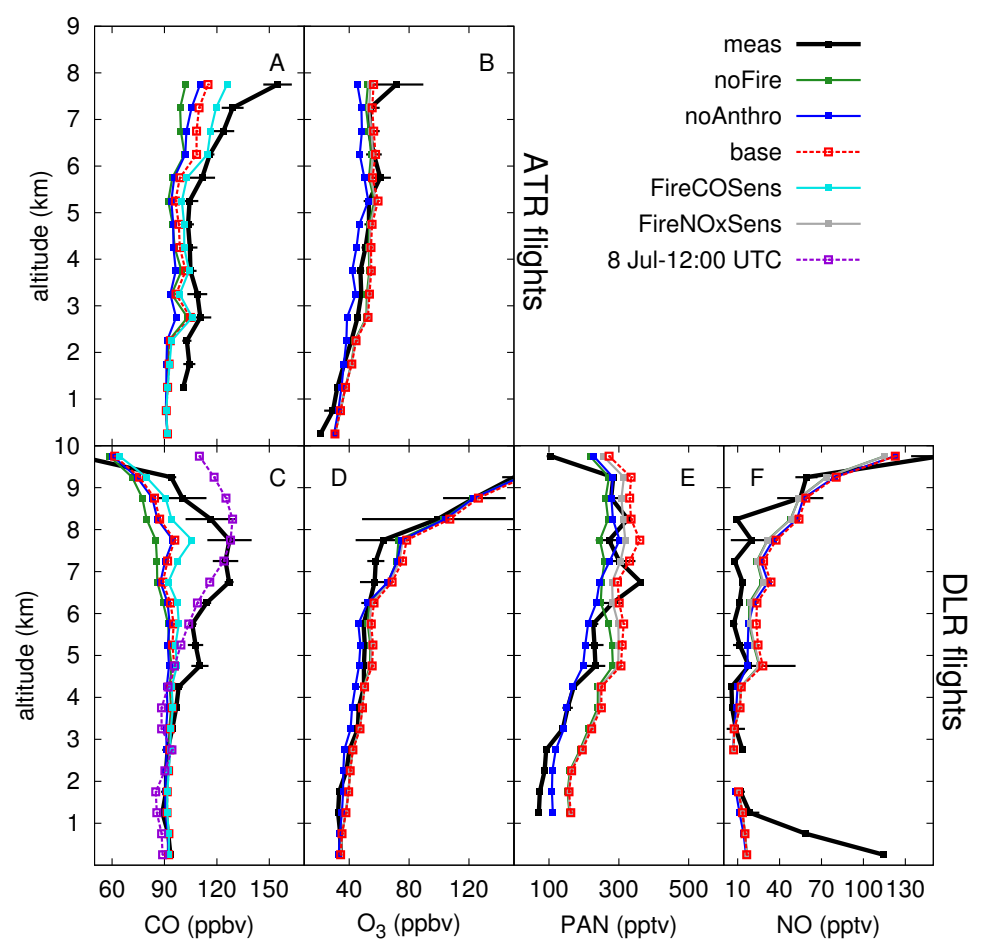

Fig. 6. Vertical profiles (averaged along flight tracks) including measurements of aged pollution compared to WRF-Chem results - measurements are in black, the model base run is in red, the noFire run is in green, and the noAnthro run is in blue. Two fire emission sensitivity runs are shown, the FireCOSens run is shown in teal (CO plot only) and the FireNOxSens run is shown in the ozone, PAN, and NO plots in gray. The points indicate mean values every $500 \mathrm{~m}$ and the error bars show the standard deviation for the measurements. The flights included for the comparison are on 5, 7, and 8 July (ATR-42 flights) and on 4, 7, and 8 July (Falcon-20 flights). In addition, one vertical profile for CO extracted from the model in the region of the Falcon-20 aircraft (lat $61.1^{\circ} \mathrm{N}$ lon $41.5^{\circ} \mathrm{W}$ ) on 8 July at 12:00 UTC is shown in purple.

a general problem and can be attributed to uncertainties in fire emissions inventories (e.g. Wiedinmyer et al., 2011).

We use ozone/CO correlations extracted along flight tracks as another measure of model performance. Over the biomass burning source region, comparisons of ozone/CO correlations for the DC8 flights are shown in Fig. 4. The highest $\mathrm{CO}$ concentrations correspond to fresh fire plumes sampled by the DC8. There is also a branch containing high ozone, low $\mathrm{CO}$ values corresponding to stratospheric air masses. The model and measured ozone/CO correlations (Fig. 4a, b) show the model under predicts $\mathrm{CO}$ pollution in fresh fire plumes. Measured fire plumes contained peak values of nearly 2 ppmv of CO (Fig. S4), which is not reproduced in the base model run. It is expected that these peak values will not be simulated by the model (using $35 \mathrm{~km}$ resolution), however, if the fires are accurately represented, the model should reproduce the average $\mathrm{CO}$ vertical profile. As already shown for the vertical profiles (Fig. 3a), the FireCOSens run, which includes additional $\mathrm{CO}$ emitted from fires, is in better agreement with the high $\mathrm{CO}$ values present in the measured ozone/CO correlations. The improved agreement between $\mathrm{CO}$ measurements and the FireCOSens run is indicated by box plots (constructed using the $\mathrm{CO}$ values in Fig. $4 \mathrm{a}-\mathrm{c}$ ) shown in Fig. 4d. Both the mean, median, lower quartile, and upper quartile show better agreement for the FireCOSens run, with notable improvement in the spread of $\mathrm{CO}$ values captured by the model for this case. The ozone/CO correlations further show that the FireCOSens run is more representative of $\mathrm{CO}$ pollution in fire plumes than the base run and that modeled ozone is rather insensitive to CO.

As an example of model performance over anthropogenic source regions, we compare with MOZAIC data collected during commercial flights in and out of Philadelphia $\left(40.0^{\circ} \mathrm{N}, 75.2^{\circ} \mathrm{W}\right)$ on 3 July ( 2 flights). These two flights contained two tropospheric profiles, making it difficult to adequately estimate the standard deviation for the measurements. Therefore, we show the measurements and model results for $\mathrm{CO}$ and ozone without the standard deviations in Fig. 5. There is very good agreement between the base model run and measurements in the free troposphere. In the boundary layer the modeled values are too high, potentially due to uncertainties in the anthropogenic emissions used or due to the fact that anthropogenic emissions are injected in the lowest model layer during the run. We examine the representation of anthropogenic plumes downwind in the 
following section to determine how much this discrepancy in the boundary layer impacts aged plumes in the model.

\subsection{Aged pollution plumes}

In order to evaluate the representation of aged BB and anthropogenic plumes measured over southern Greenland, we use data collected onboard the French and German aircraft, which targeted aged pollution during POLARCAT (see Table 1 for the list of flights). Vertical profiles constructed using the ATR-42 and Falcon-20 measurements and corresponding model results are shown in Fig. 6.

For the ATR-42 CO (Fig. 6a) and ozone (Fig. 6b), the results from the base run agree well with the measurements in the mid-troposphere. In the upper troposphere, modeled $\mathrm{CO}$ is too low, for example at $8 \mathrm{~km}, 150 \mathrm{ppbv}$ was measured compared to $120 \mathrm{ppbv}$ in the model. The FireCOSens run, with additional $\mathrm{CO}$ emissions, is in better agreement with $\mathrm{CO}$ measurements in the upper troposphere. This shows that $\mathrm{CO}$ emissions in North America impact CO concentrations in the free troposphere downwind due to plumes that are strongly uplifted during transport. This also suggests that the low bias in modeled $\mathrm{CO}$ is primarily due to Canadian fire emissions in the base run. Imperfect representation of the location of plumes in the model may be another cause of the low bias in modeled fire plumes downwind. For example, on 8 July (see Fig. S5), the ATR-42 aircraft measured a high $\mathrm{CO}$ air mass $(\mathrm{CO}>160 \mathrm{ppbv})$ during a flight leg at $8 \mathrm{~km}$ between 14:30 and 15:20 UTC. Figure $2 \mathrm{f}$ clearly shows this air mass was in the region of the aircraft, but the modeled peak CO concentrations ( $\sim 160 \mathrm{ppbv}$ at $8 \mathrm{~km})$ are east of the flight track. There is also a potential contribution from low CO in the MOZART-4 initial and boundary conditions (Fig. S8). While the same emissions are used for both WRFChem and MOZART-4, the negative bias in $\mathrm{CO}$ can originate from differences in the model resolution and the corresponding ability to resolve plumes spatially or from Asian emissions, which may be too low in the emissions (e.g. Shindell et al., 2008, Fisher et al., 2010). The ozone profile for the base model run for the ATR-42 flights shows that the model represents the measured ozone profile reasonably well. It is important to note that while NMHCs in fresh fire plumes (discussed earlier for the DC8 measurements) are underpredicted by the model, the resulting ozone profiles in the Arctic region agree very well with the measurements. Even so, we note that ozone production in fire/anthropogenic plumes, as represented in WRF-Chem, may be a lower limit for ozone production in the atmosphere due to the underprediction of these species in fire plumes.

For the Falcon-20 flights, $\mathrm{CO}$ between $6-9 \mathrm{~km}$ is too low in the base model run (Fig. 6c), for example, at $8 \mathrm{~km}, 130 \mathrm{ppbv}$ was measured compared to $90 \mathrm{ppbv}$ peak in the model. Again, the FireCOSens run is in better agreement with the measured CO levels, but still contains a low bias ( $20 \mathrm{ppbv})$ in the mid- and upper troposphere. The cause for the low CO in the model may also originate from MOZART-4. However, as already discussed for the ATR-42 comparisons, plume location is also an important factor in the low bias. For example, on 8 July, the modeled fire plume is south of the Falcon-20 flight track (Fig. 2f), suggesting that uncertainties in modeling the transport between North America and Greenland may also contribute. To evaluate if the shape of the $\mathrm{CO}$ profile measured by the Falcon-20 is consistent with model, we also show one vertical profile (Fig. 6c) extracted from the model on 8 July near the flight track. This shows clearly that pollution plumes are present at the correct altitude in the model, but the location of the pollution plumes does not overlap with the flight track. Modeled ozone and NO (Fig. 6d, f) are in good agreement with the measurements throughout the troposphere, while noting that in the region between 6-9 km, the model has higher NO mixing ratios than measured. However, for the altitudes with long flight legs (See SI, Fig. 3) comprising the majority of measurements $(5 \mathrm{~km}, 7.5-8 \mathrm{~km}$, and $8.5-9 \mathrm{~km}$ ) the model is within one standard deviation of the measurements. Below $1 \mathrm{~km}$, the measurements reflect local NO pollution from airport/local anthropogenic emissions in Kangerlussuaq, Greenland, which are underrepresented in the emissions inventory. The modeled PAN (Fig. 6e) agrees with measurements in the upper troposphere, but has a positive bias in the mid- and lower troposphere.

The ozone/CO correlation plots for the ATR-42 and Falcon-20 flights provide a measure of model representation of ozone production in aged pollution plumes (Fig. 7). For the ATR-42 flights (Fig. 7a, b), the base model run underpredicts both ozone and $\mathrm{CO}$ along the ATR-42 flight tracks. There is an influence from stratospheric air masses, shown as high ozone, low $\mathrm{CO}$ points on the correlation plots. On 8 July, when the ATR-42 flew in the same region as the Falcon20 flew one day earlier, high $\mathrm{CO}$ air masses were observed $(\mathrm{CO}>150 \mathrm{ppbv})$, which are not reproduced in the base run. A portion of the low bias in model CO levels for the ATR42 flights originates from the low bias in $\mathrm{CO}$ in fresh Canadian fires, with a second contribution from the MOZART-4 boundary conditions. There are also high $\mathrm{CO}$, high ozone air masses that were observed by the ATR-42, that have lower ozone concentrations in the model. During the Falcon-20 flights (Fig. 7e,f), the model has good agreement with measured ozone values, including correct representation of ozone in the UTLS (ozone $>100 \mathrm{ppbv}$ ). In general, the model correctly captures the shape of the ozone/CO correlation plot, but the $\mathrm{CO}$ values are too low in the base model run. The FireCOSens run is shown for both sets of flights (Fig. 7c, $\mathrm{g}$ ), and again shows better agreement with the measurements than for the base model run. Better agreement for the FireCOSens is also shown for both sets of flights in the box and whisker plots in Fig. 7d and h. 

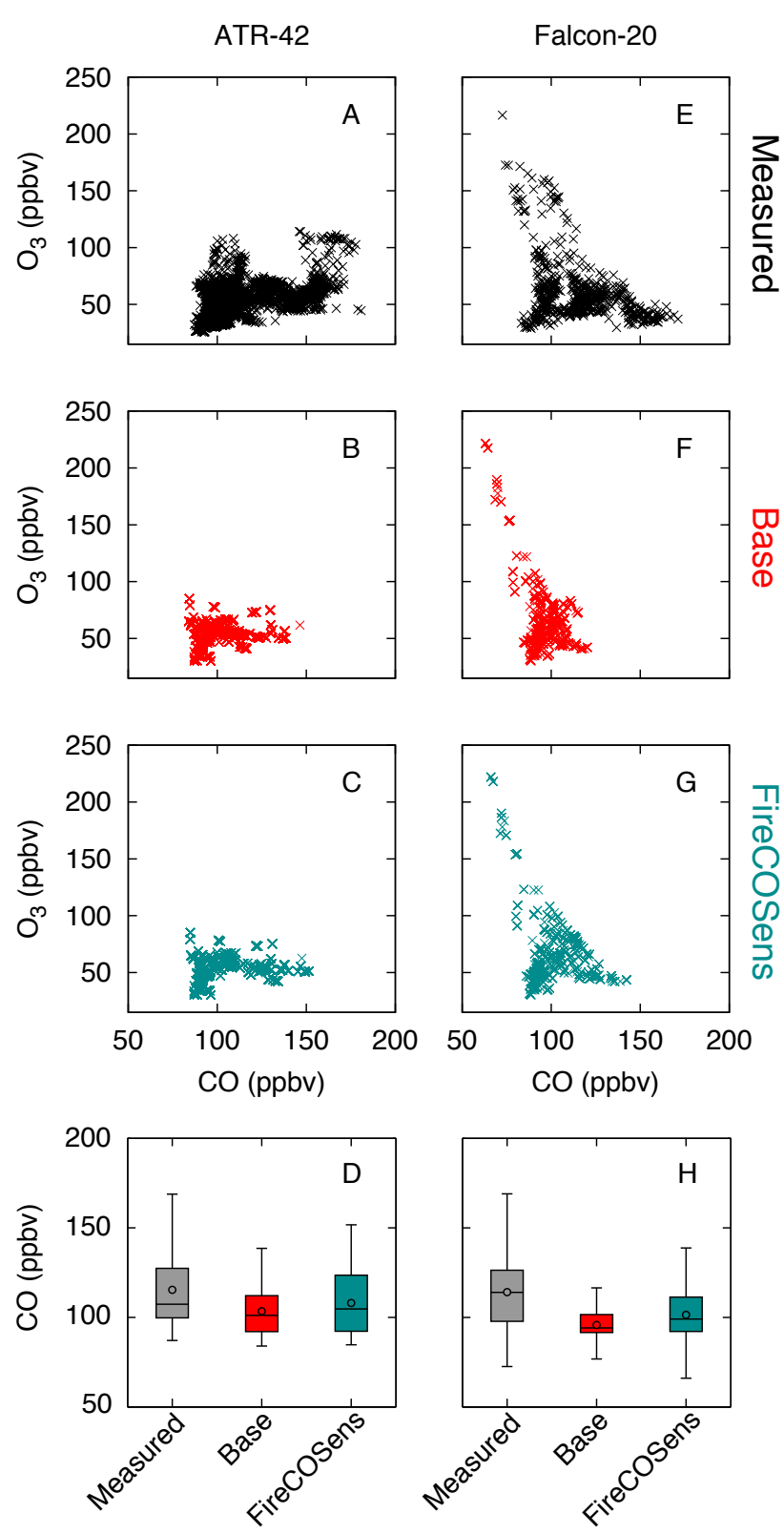

Fig. 7. Ozone versus CO correlations for the ATR-42 (a) and Falcon-20 (e) data, model base run (b) and (f) and a model run with $\mathrm{CO}$ emissions from fires x2, FireCOSens (c) and (g) for ATR-42 flights on 5, 7 and 8 July 2008 and Falcon-20 flights on 4, 7 and 8 July. For comparison, model results are extracted along the ATR42 and DLR Falcon-20 flight tracks. Box and whisker plots for CO (measurements, model base run, and FireCOSens run) are shown in panels (d) and (h). For these plots, the box indicates the $25 \%$ and $75 \%$ percentiles, the line represents the median, and the circle shows the mean.

\section{Plume origin and aging}

Given that the focus of our study is ozone production in aged plumes during transport to the Arctic, we focus on selected plumes measured downwind over Greenland. In this section, we focus on one fire and one anthropogenic air mass measured by the ATR-42 over Greenland to investigate in more detail aged plume composition and origin. It is essential to look at individual plumes to understand ozone production during transport because the aircraft also measured a large number of non-polluted air masses, making it difficult to examine ozone production in plumes using campaign averages (as noted earlier). For this analysis, we use plumes sampled by the ATR-42 on 5 and 7 July. We have chosen these flights because there are pollution plumes that are correctly captured by the model and because of the availability of ozone lidar data taken onboard the aircraft. The model and measurement data for both flights are shown in Figs. 8-10 and each flight is discussed individually in the sub-sections that follow. Specifically, $\mathrm{CO}$ and ozone predicted in the base, noAnthro, noFire, FireCOSens model runs for these flights are shown in Fig. 8. During both flights, there are two broad polluted air masses that were measured during different flight segments.

\subsection{ATR-42 flight on 5 July 2008}

On 5 July, enhancements in $\mathrm{CO}$ were measured during flight segments at $6 \mathrm{~km}$ (11:50 UTC, up to $120 \mathrm{ppbv})$ and below $4 \mathrm{~km}$ (12:20 UTC, up to $145 \mathrm{ppbv})$. In the model, a first pollution plume is predicted at $6 \mathrm{~km}$ (between 11:45-12:15 UTC) and a second plume is predicted for the lower altitude leg, after descent below $4 \mathrm{~km}$ (between 12:20-12:50 UTC). The measurements show broad enhancements in $\mathrm{CO}$ during these flight legs, as well as finer structure, including sharp enhancements in $\mathrm{CO}$ that are not reproduced by the model due to resolution. In general, the base model run is in good agreement with the measurements for both $\mathrm{CO}$ (Fig. 8a) and ozone (Fig. 8b), noting that at $4 \mathrm{~km}$ the $\mathrm{CO}$ maximum occurs slightly later in the model than in the measurements, representing a spatial displacement of the plume of $70 \mathrm{~km}$ in the model from where it was seen by the aircraft. This spatial displacement of the plume represents very good agreement for an aged plume that has undergone long-range transport in a high-resolution model run. The model sensitivity runs (noAnthro and noFire) provide insight into plume origin and the relative contribution from anthropogenic and fire pollution. For this flight, the noAnthro run has much lower $\mathrm{CO}$ for both plumes, clearly demonstrating they are of anthropogenic origin. While the ozone levels in these plumes are not clear peaks in the base model run, the noAnthro run shows that without anthropogenic emissions to sustain ozone levels in these plumes, ozone mixing ratios would be much lower than measured ( $>30 \mathrm{ppbv}$ difference with vs. without emissions). During the descent at 12:15 UTC (Fig. 8b), the aircraft measured relatively high ozone that was co-located with a dip in 


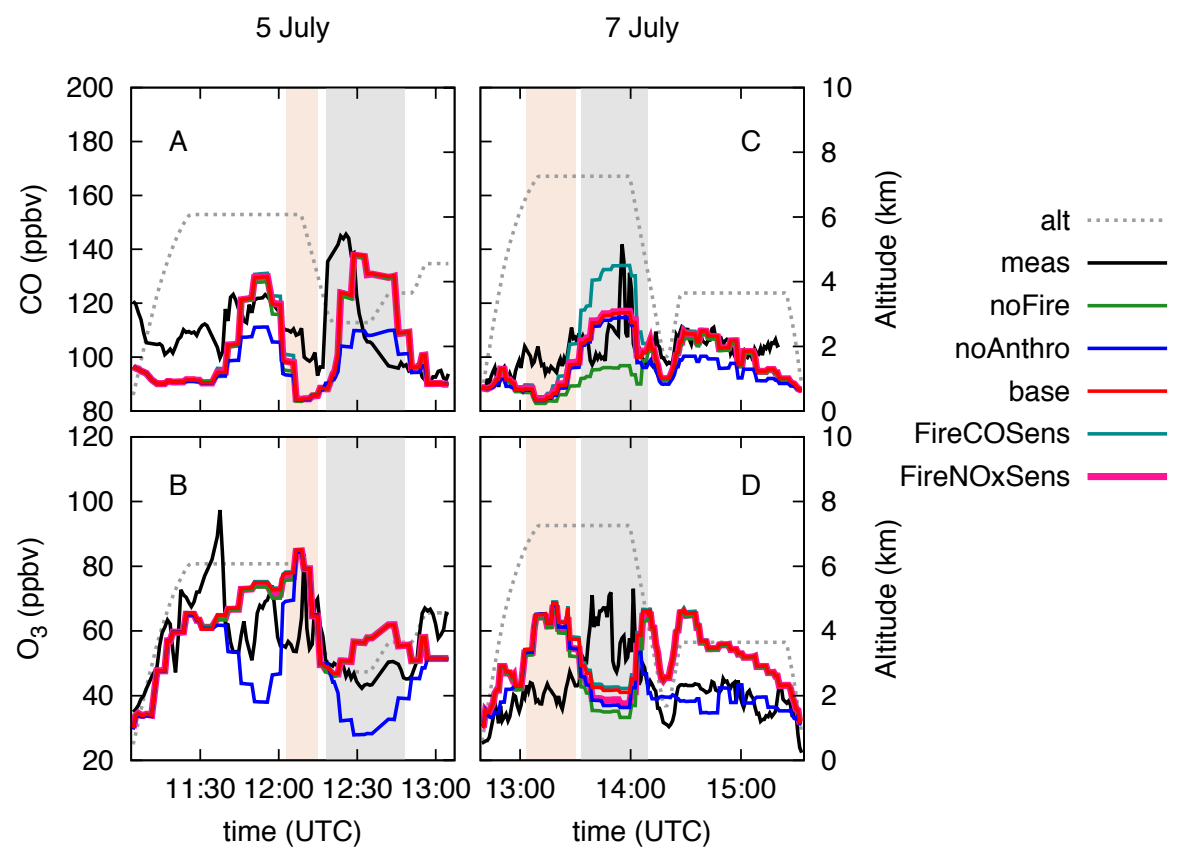

Fig. 8. Comparison of WRF-Chem results with measurements made onboard the ATR-42 aircraft on 5 and 7 July. Measurements are in black, the model base run is in red, the noFire run is in green, the noAnthro run is in blue, and the FireCOSens run is in teal. The dashed line represents the aircraft altitude. The plumes investigated in more detail are highlighted using the gray background. High ozone air masses in the model are highlighted using the tan background. See text for details.
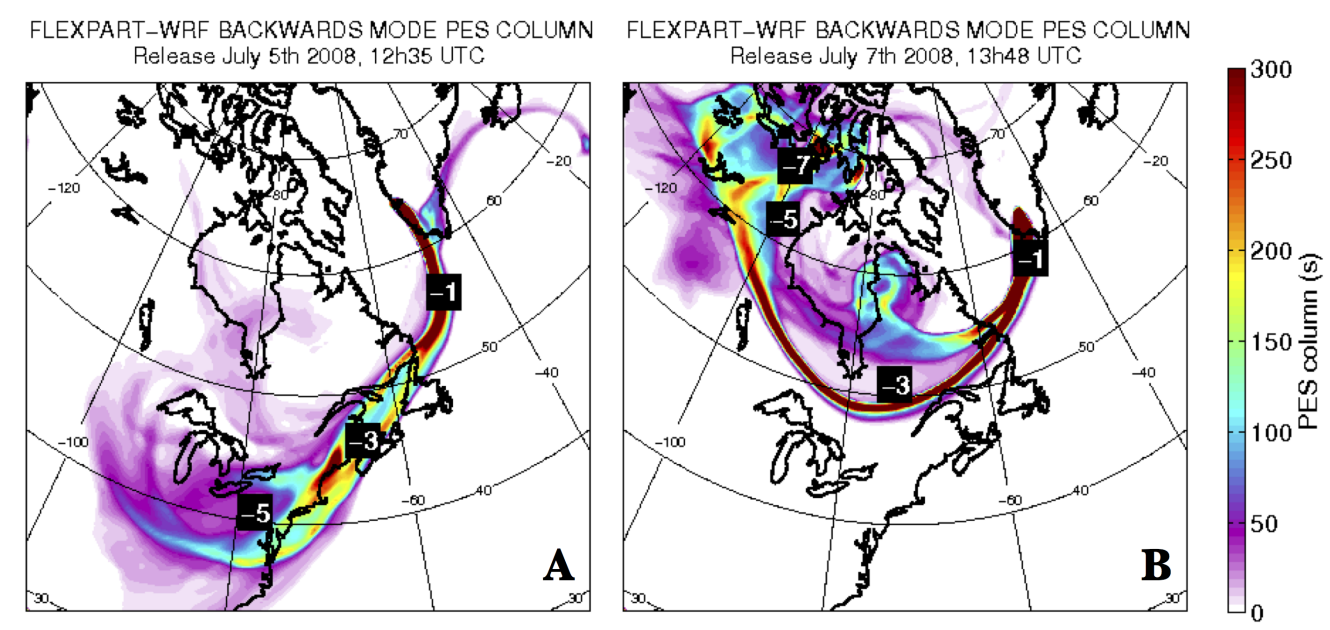

Fig. 9. FLEXPART-WRF potential emissions sensitivities (PES) for the second plume sampled by the ATR-42 aircraft on 5 July 2008 at 12:30 UTC (a) and the first plume sampled on 7 July 2008 at 13:45 UTC (b), the location of the average emission sensitivity for each day prior to the release time are also indicated in white. The emissions sensitivities show clearly that the plumes have different origins; the plume sampled on 5 July is anthropogenic in origin, while the first plume on 7 July originates from the region where boreal forest fires were burning in June-July 2008.

observed $\mathrm{CO}$, indicating the presence of a non-polluted air mass in this region (highlighted in tan) which is also present in the model. We discuss the origin of this air mass later in the context of ozone lidar measurements onboard the ATR42 aircraft.
Focusing on the second peak in modeled $\mathrm{CO}$ on 5 July (highlighted in gray in Fig. 8a), we look in more detail at the plume origin using FLEXPART-WRF. Emissions sensitivities were calculated backwards from the time and altitude of this plume in the model (shown in Fig. 9a). Emissions 

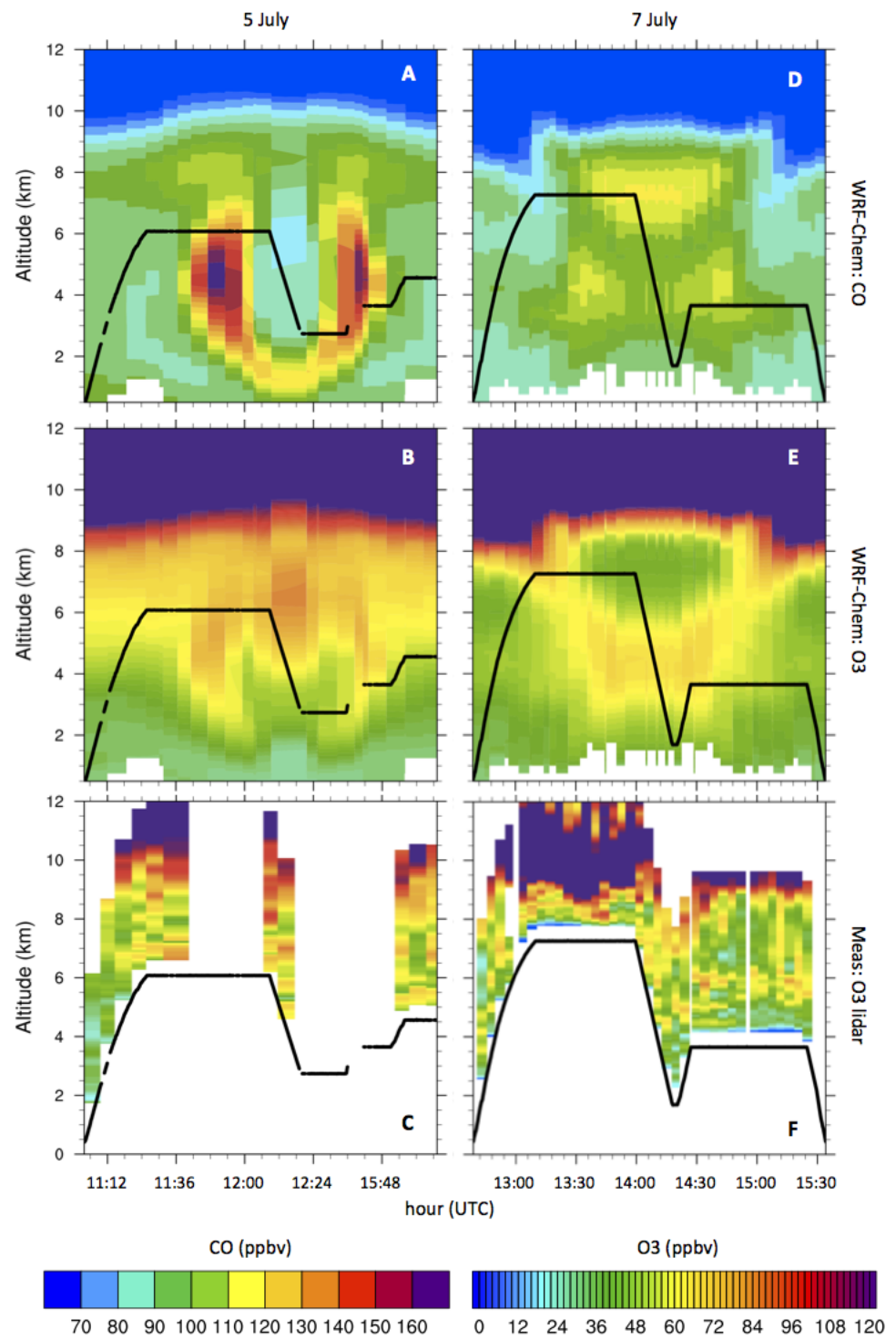

Fig. 10. Model results and measured lidar profiles from the ATR-42 flights on 5 and 7 July. Vertical cross sections of CO (a) and (d) and $\mathrm{O}_{3}$ (b) and (e) along ATR-42 flight tracks extracted from WRF-Chem demonstrate the extent of plumes as modeled by WRF-Chem over southern Greenland. Bottom panel (c) and (f) shows ozone lidar plots from measurements made onboard the ATR-42 aircraft.

sensitivities confirm the plume is anthropogenic in origin, with contributions from the northeastern United States 3-5 days before the plume arrived over southern Greenland.

The plumes are also investigated using vertical cross sections extracted from WRF-Chem along the ATR flight tracks (Fig. 10a-b) and compared to ozone lidar data taken onboard the aircraft (Fig. 10c). The model predicts elevated $\mathrm{CO}$ along the flight track (Fig. 10a) with pollution extending from 3$7 \mathrm{~km}$. The behavior of ozone is more complicated than $\mathrm{CO}$ because of the contribution from high ozone stratospheric air masses to ozone levels in the UTLS. Modeled ozone of anthropogenic origin is co-located with modeled $\mathrm{CO}$ on 5 July (Fig. 10b), with similar vertical extent for plumes. There is also a high ozone air mass present in the model that occurs with low modeled CO at 12:15 UTC, which likely originates from the stratosphere. A vertical cross section showing model-predicted potential vorticity (PV) along the flight track (Fig. S9a) indicates that this air mass is partially stratospheric in origin due to the higher PV values ( $\sim 0.6 \mathrm{PVU})$ than the surrounding air ( $\sim 0.4 \mathrm{PVU})$.

Onboard the aircraft, the lidar was aimed in the upward direction, therefore no measurements are available below the flight track. White bands with no lidar data during the flight indicate the detection of clouds, preventing the retrieval of measured ozone mixing ratios. The tropopause is slightly lower $(9 \mathrm{~km})$ in the model than measured by the 
lidar $(10 \mathrm{~km})$. Enhanced ozone was observed by the lidar just above the aircraft at $6.5 \mathrm{~km}$ at 11:30 UTC, which may be the beginning of the anthropogenic plume or could be enhanced ozone due to a stratospheric intrusion (indicated by enhanced PV in the model extending down to $4 \mathrm{~km}$ in Fig. S9a). The high ozone band present in the model at 12:15 UTC is also seen in the lidar data, which indicates a tropopause folding event. As noted earlier, the model PV values associated with the high ozone, low CO air mass at 12:15 UTC do not indicate a completely stratospheric origin. FLEXPART-WRF analysis (not shown) point to a stratospheric contribution (> $10 \%$ ) for this air mass 3-6 day earlier, explaining the moderate PV values and elevated ozone. The PV as well as the low CO levels in the model simulation indicate that the pollution plume was located between air masses with high ozone that do not originate from pollution, but originate from the stratosphere several days before the plume was measured by the aircraft.

\subsection{ATR-42 flight on 7 July}

On 7 July, pollution was measured during two flight segments at $7 \mathrm{~km}$ and $4 \mathrm{~km}$ (Fig. 8c). Sharp peaks in CO were measured during the first leg (13:50 UTC, $>140$ ppbv), which are superimposed on a broad $\mathrm{CO}$ enhancement ( $>100 \mathrm{ppbv}$ ). During the second flight leg, less enhanced $\mathrm{CO}$ values were measured at $4 \mathrm{~km}$. Modeled $\mathrm{CO}$ for the base run captures the general structure of the $\mathrm{CO}$ features during the flight, however the sharp peaks are not reproduced (as discussed above) due to model resolution. The model sensitivity runs (noFire and noAnthro) show that the $\mathrm{CO}$ enhancements during the first flight leg $(7 \mathrm{~km})$ originate from Canadian fires. While the observed enhancements in CO during the second flight leg are not as apparent ( $\sim 110 \mathrm{ppbv})$, the model run without anthropogenic emissions underpredicts $\mathrm{CO}$ compared to the measurements, showing that the small enhancement in $\mathrm{CO}$ at $4 \mathrm{~km}$ is anthropogenic in origin. We also show the results for the FireCOSens run because it has demonstrated better agreement with measured $\mathrm{CO}$ values. The FireCOSens run has additional $\mathrm{CO}$ from fires ( $>130$ ppbv CO) during the first flight leg, which is more in line with the measured peak values, but the modeled enhancement in $\mathrm{CO}$ occurs over a longer portion of the flight leg than in the measurements.

Understanding the ozone values measured during this flight are complicated by stratospheric intrusions that enhance ozone in the UTLS due to the low tropopause height in the Arctic (discussed earlier for 5 July). The ozone peak on 7 July just after 13:30 UTC in the measurements (highlighted within the gray box, Fig. 8d) is related to a stratospheric air mass (see ozone lidar discussion) in the region the aircraft was flying (peak ozone $>60 \mathrm{ppbv}$ ). A polluted fire air mass was encountered just after the stratospheric intrusion (two sharp peaks in CO at 13:50 UTC), also highlighted within the gray box. The level of ozone in the stratospheric air mass is correctly reproduced by the model (peak value of $60 \mathrm{ppbv}$ ozone), but occurs earlier in the model than measured (highlighted in the tan box, Fig. 8d). Ozone in the fire plume is lower than measured ( $40 \mathrm{ppbv}$ in the model compared to an average of $\sim 55 \mathrm{ppbv}$ measured). However, mixing between the stratospheric air mass and BB plume may have contributed to higher ozone in the measurements. This may not occur as efficiently in the model due to the timing of these peaks, which shows clear separation of the air masses in the model.

The FLEXPART emission sensitivities (Fig. 9b) for the fire plume on 7 July (highlighted in gray in Fig. 8b) show that it originated from the BB region over Canada 5-7 days before the flight, indicating longer transport times than for anthropogenic plumes. The source region corresponds to the location where the DC8 flew as part of ARCTAS-B, connecting measurements made in fresh fire plumes and this ATR-42 flight, which measured aged BB pollution.

Vertical cross sections extracted from the model on 7 July (along the flight track) are shown in Fig. 10d-e. The extent of $\mathrm{CO}$ enhancements for the base model run on 7 July are shown in Fig. 10d. The model predicts that the fire plume sampled along the flight leg at $7 \mathrm{~km}$ extends between $6-8 \mathrm{~km}$. Plots for the FireCOSens run are not shown, but contain additional enhancements in $\mathrm{CO}$ of up to $20 \mathrm{ppbv}$ from 6-8 $\mathrm{km}$. The model also predicts a lower altitude plume $(\sim 4 \mathrm{~km})$ that crosses the flight track after 14:30 UTC, which is anthropogenic in origin according to the FLEXPART emission sensitivities and WRF-Chem model emissions sensitivity runs. On 7 July, ozone originating from the stratosphere is clearly visible in the model $\left(\mathrm{O}_{3}>60 \mathrm{ppbv}\right)$ between the anthropogenic air mass $(\sim 4 \mathrm{~km})$ and fire pollution $(\sim 7 \mathrm{~km})$ as part of a stratospheric fold (Fig. 10f). This layer corresponds to low CO mixing ratios in the model (Fig. 10d). The fire pollution was lifted above this stratospheric fold and contains lower ozone than in the surrounding air mass. However, the BB plume has ozone that has been formed photochemically rather than transported from the stratosphere.

On 7 July, the lidar data (Fig. 10f) clearly show a fold structure along the flight at 13:45 UTC when there is a large ozone peak apparent in the in situ measurements (Fig. 8d). The fold is also predicted by the model (discussed above) but crosses the flight track at 13:15 UTC (also seen as enhanced modeled PV in Fig. S9b). The lidar data also shows a high ozone stratospheric air mass that was encountered at the beginning of the descent from $7 \mathrm{~km}$ to $2 \mathrm{~km}$ at 14:00 UTC (seen at $6 \mathrm{~km}$ ). The model may be underpredicting ozone produced in the BB layer because of underrepresentation of mixing between stratospheric air masses with this fire plume.

\section{Ozone production in plumes}

Ozone production in BB plumes has been the subject of a number of studies, with conflicting results as to the extent 
of ozone production that occurs. Jaffe and Wigder (2012) recently reviewed current knowledge of ozone production from wildfires and concluded that the majority of studies show that $\mathrm{O}_{3}$ production occurs in $\mathrm{BB}$ plumes downwind from emission regions. They also showed that in $\mathrm{BB}$ plumes, typical measured $\Delta \mathrm{O}_{3} / \Delta \mathrm{CO}$ ratios (where $\Delta \mathrm{O}_{3}$ and $\Delta \mathrm{CO}$ represent enhancements over background concentrations in fire plumes) range from 0.1 to 0.9 , with higher values for plumes aged more than 5 days. It is well known that BB emissions contain ozone precursors (e.g. Crutzen et al., 1979; Andreae and Merlet, 2001) and most observations show that ozone production occurs in plumes (e.g. Mauzerall et al., 1998; Singh et al., 2000; Jaffe et al., 2001, 2004; McKeen et al., 2002; Honrath et al., 2004; Pfister et al., 2006, 2008; Val Martin et al., 2008; Real et al., 2007; Oltmans et al., 2010, Akagi et al., 2011). In boreal regions, the focus of the present study, the evidence for ozone production is less clear because it has been suggested that $\mathrm{O}_{3}$ was not produced in plumes sampled during ARCTAS-B (e.g. Alvarado et al., 2010; Singh et al., 2010). Recently, Wespes et al. (2012) showed that the contribution of $\mathrm{BB}$ to ozone along the summer (ARCTAS-CARB and ARCTAS-B) DC8 flight tracks was significant in the lower troposphere (pressure $>700 \mathrm{hPa}$ ) but only contributed a small amount higher in the troposphere. Parrington et al. (2012) recently showed that model (GEOSChem) ozone distributions in coastal Canada are very sensitive to $\mathrm{NO}_{\mathrm{x}}$ emissions from biomass burning sources in central Canada during 2010, suggesting ozone production occurs in Canadian fire plumes after aging. Furthermore, chemistry in $\mathrm{BB}$ plumes can be impacted by mixing with $\mathrm{NO}_{\mathrm{x}}$-rich anthropogenic emissions during transport, resulting in additional ozone formation (e.g. McKeen et al., 2002). Chemistry can be complicated by mixing with high ozone, stratospheric air masses, which can occur in and near the Arctic due to the low tropopause height (as discussed in Liang et al., 2011). Recently, Wespes et al. (2012) noted that import from the stratosphere is the principal source of ozone for pressures less than $450 \mathrm{hPa}$. The transport of pollution into the Arctic is particularly important because ozone production continues within the Arctic with an important contribution from PAN decomposition originating from transported pollution (Walker et al., 2012).

In this section, we examine the overall impact of $\mathrm{BB}$ and anthropogenic plumes on ozone levels throughout the model domain during the study period. The goal is to provide a measure of ozone production in plumes originating from North America on a wider spatial scale than covered by the aircraft measurements. Based on comparison of model results with campaign average vertical profiles, the extent of ozone production appears rather limited (base vs. noFire runs, Figs. 3 and 6), which is consistent with the profiles presented in Alvarado et al. (2010) and Wespes et al. (2012). However, for individual plumes we have shown that fire emissions result in significant ozone enhancements (Fig. 8d). Here, we use differences between model runs (e.g. base-noFire,
base-noAnthro) to estimate the amount of ozone produced in plumes during transport towards the Arctic. Results are presented for both anthropogenic and BB plumes to compare their relative contribution to ozone produced during longrange transport.

\subsection{Enhancement of $\Delta \mathrm{O}_{3} / \Delta C O$ in plumes}

The slope of the correlation between ozone and $\mathrm{CO}$ has been used as a measure of ozone production in air masses originating from different emission sources (e.g. Parrish et al., 1993). For example, the observed ozone/CO correlation in Fig. 7a contains enhanced ozone in high $\mathrm{CO}$ plumes (slope of 0.24). However, this slope contains both enhancements in ozone due to mixing with the stratosphere and with clean air masses, and it also mixes the contributions from anthropogenic and fire plumes. Therefore, we use another measure of ozone production in plumes, enhancement ratios calculated from differences between model runs with and without emissions, to calculate ratios in plumes due to a specific source. The enhancement ratios $\left(\Delta \mathrm{O}_{3} / \Delta \mathrm{CO}\right)$ are defined as the excess $\mathrm{O}_{3}$ mixing ratio due to a particular source as a function of increased $\mathrm{CO}$ from the same source. We use differences between model runs with and without emissions to calculate $\Delta \mathrm{CO}$ or $\Delta \mathrm{O}_{3}$ enhancements, where $\Delta$ refers to plumes present in the base model run, but missing from the run without emissions. This follows the approach in Pfister et al. (2006), a study which used MOZART runs with and without BB emissions to estimate the enhancements of $\mathrm{CO}$ and ozone in aged boreal forest fire plumes measured at the PICO-NARE station located in the Azores. We note that non-linearities in ozone photochemistry may influence our results, although Pfister et al. (2006) only found small sensitivities to the method employed to estimate enhancement ratios. The spatial extent of modeled $\Delta \mathrm{O}_{3}$ for an anthropogenic and fire plume encountered by the ATR-42 on 5 July and 7 July (discussed earlier in Sections 4.1 and 4.2) are shown in Fig. 11. On 5 July (Fig. 11a), the ATR-42 transected a large anthropogenic pollution plume with simulated ozone enhancements up to $60 \mathrm{ppbv}$ during transport to the Arctic. During the flight on 7 July (Fig. 11b), the model predicts ozone enhancements of up to $20 \mathrm{ppbv}$ in fire plumes at $7 \mathrm{~km}$. In a prior study, McKeen et al. (2002) used a regional chemical transport model in a similar manner, using runs with and without fire emissions to show that ozone formed in BB plumes contributed significantly to ozone mixing ratios in the continental United States. This study showed that on 2 July 1995 ozone mixing ratios were predicted to increase up to $30 \mathrm{ppbv}$ (at the surface) in the eastern US due to fire emissions. In our study, the large spatial extent of modeled plumes (including fire plumes) is apparent in Fig. 11 as demonstrated by the ozone enhancements that occur over a large portion of the domain. The ozone enhancements occur with enhanced $\mathrm{CO}$, shown as elevated $\mathrm{CO}$ values in Fig. 2 for these same plumes. 


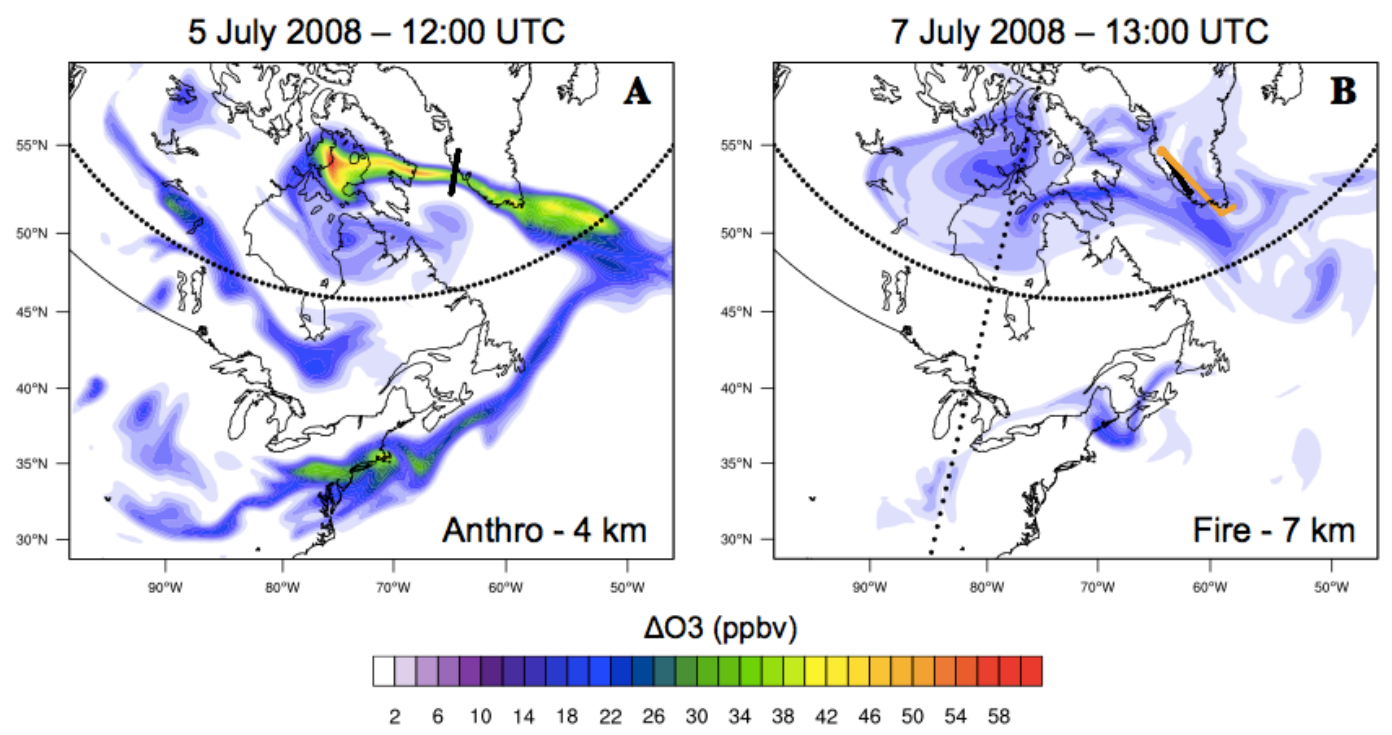

Fig. 11. Maps of enhancements in ozone in anthropogenic and fire plumes $\left(\Delta \mathrm{O}_{3}\right)$ demonstrating the spatial extent of plumes sampled by the ATR-72 and Falcon-20 on 5 and 7 July 2008. The ATR-42 aircraft flight tracks are in black and the Falcon-20 flight track is in orange. For anthropogenic plumes, the latitude $55^{\circ} \mathrm{N}$ that is used to define fresh $\left(<2 \mathrm{~km}\right.$, lat $\left.<55^{\circ} \mathrm{N}\right)$ and aged $\left(\right.$ lat $\left.>55^{\circ} \mathrm{N}\right)$ anthropogenic plumes is indicated by the dotted black line. For fire plumes, the latitude $55^{\circ} \mathrm{N}$ longitude $85^{\circ} \mathrm{W}$ (used to define aged fire plumes) are indicated by dotted black lines. These same plumes are shown as enhanced CO mixing ratios in Fig. 2, panel (d) for the anthropogenic emissions and panel (e) for fires.

In order to understand the evolution of $\mathrm{CO}$ and ozone enhancements in anthropogenic and fire plumes during transport to the Arctic, the model domain was divided into regions containing fresh and aged plumes. For fresh anthropogenic plumes, model grid cells south of $55^{\circ} \mathrm{N}$ and below $2 \mathrm{~km}$ were used to limit our analysis to fresh emissions in the boundary layer. Due to the the nature of fires, different regions were used each day to calculate enhancements, with the goal of limiting the analysis to very fresh boreal fire plumes. The Canadian fire emissions (lat $>55^{\circ} \mathrm{N}$ ) for each day were used to define a lat/lon region containing fresh fires (including cells with at least than $5 \%$ of the peak emissions). An example of the region used for fresh fire plumes on 1 July 2008 is shown in Fig. S10. For aged anthropogenic air masses, grid cells with lat $>55^{\circ} \mathrm{N}$ were used to calculate ozone and $\mathrm{CO}$ enhancements. For aged fire plumes, latitudes north of $55^{\circ} \mathrm{N}$ and east of $85^{\circ} \mathrm{W}$ were used to define aged fire pollution. We then calculate a probability distribution for $\Delta \mathrm{O}_{3}$ vs. $\Delta \mathrm{CO}$ for fresh and aged anthropogenic and fire plumes. Daily distributions were calculated as bidimensional histograms using 1 ppbv bins for $\Delta \mathrm{O}_{3}$ and $5 \mathrm{ppbv}$ bins for $\Delta \mathrm{CO}$ and then the distributions were normalized such that the values plotted represent a probability distribution. The probability distributions for 1, 3, 5, and 7 July are shown (Fig. 12) using $\Delta \mathrm{CO}$ and $\Delta \mathrm{O}_{3}$ values calculated from the base-noAnthro, basenoFire, and FireCOSens-noFire runs. There is a complex relationship between modeled $\Delta \mathrm{O}_{3}$ and $\Delta \mathrm{CO}$ enhancements, with each individual distribution representing both a spatial and temporal average. To characterize the distributions for each day, we use the maximum probability $\Delta \mathrm{O}_{3}$ value for each $\triangle \mathrm{CO}$ bin. Both the lines and slopes for each line are shown in Fig. 12 and the average slopes for 1-8 July 2008 are given in Table 2 .

Fresh anthropogenic plumes have relatively high $\Delta \mathrm{O}_{3} / \Delta \mathrm{CO}$ slopes (average slope of 0.63 ) and higher values for aged plumes (average slope 0.92). The slopes for fresh plumes are higher than values reported for anthropogenic air masses from northeastern North America sampled at low altitudes, downwind of emission regions (e.g. ratio of 0.3 by Parrish et al., 1993). The increase in slope as plumes are transported north indicates that ozone production continues to occur during transport. The slopes for aged emissions are twice the value of 0.5 reported by Real et al. (2008) for low level, aged plumes. However, our values are consistent with ozone/CO enhancements in anthropogenic air masses reported in other studies (ratios of -0.06 to 1.52 by Price et al., 2004 for Eurasian anthropogenic air masses, and ratios 3-4 larger for anthropogenic than for fire plumes reported by Pfister et al., 2006). The enhancement ratios show that ozone production in anthropogenic plumes was significant near and in the Arctic during the modeled period in summer 2008.

Fresh fire plumes have much higher $\Delta \mathrm{CO}$ values than anthropogenic plumes, but are not strongly enhanced in ozone (Fig. 12c, i, o, u), with an average slope of 0.08 when the enhancements are calculated using the base run and 0.07 when enhancements are calculated using the FireCOSens run. These fresh fires comprise the majority of plume 


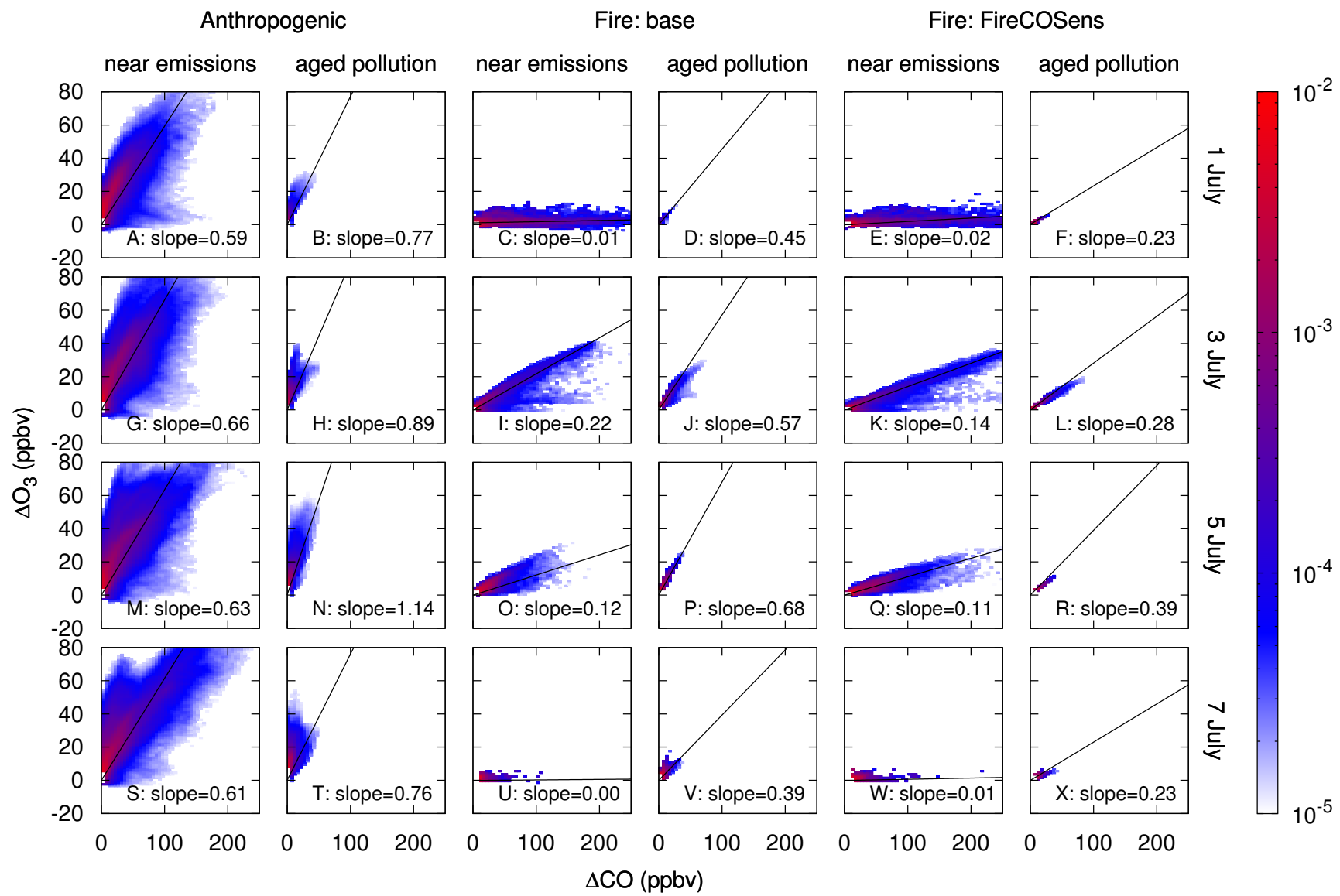

Fig. 12. Ozone versus CO enhancements for anthropogenic (left) and fire (base: center, FireCOSens: right) plumes on 1, 3, 5, and 7 July. The color bar indicates the probability (unitless) that a model grid cell will contain the corresponding $\Delta \mathrm{O}_{3}$ and $\Delta \mathrm{CO}$ value. The slopes were calculated from the $\Delta \mathrm{O}_{3}$ and $\Delta \mathrm{CO}$ values over $24 \mathrm{~h}$ for the regions defined for fresh and aged pollution. See text for details.

measurements made onboard the DC8 during ARCTAS-B, and the low ozone enhancements are consistent with the conclusion that there was little or no ozone production in fire plumes close to the emission region (Singh et al., 2010). Downwind however, the slope of $\Delta \mathrm{O}_{3} / \Delta \mathrm{CO}$ increases significantly for aged fire plumes (average ratio of 0.49 using the base run and 0.26 using the FireCOSens run), indicating ozone production occurred farther downwind. For FireCOSens run, the slope is lower because ozone levels are relatively insensitive to $\mathrm{CO}$ concentrations on the timescale of several days, therefore the slope is approximately half of that for the base model run upon doubling the $\mathrm{CO}$ emissions from fires. Near the source region, the spatial and temporal resolution of the fire emissions inventory used (FINNv1) and the fire injection height result in different fresh plume compositions on different days, as shown by the difference between fresh fire plumes on 1, 3, 5, and 7 July in Fig. 8. For aged plumes, the distributions indicate that fire plumes form ozone during transport. Aged plumes have lower CO levels, which are reduced primarily due to mixing with clean air masses during transport. The enhancement ratio of 0.49 for fire plumes is in the mid-range of ozone/CO enhancements for aged fire plumes summarized in Jaffe and Wigder (2012). The downwind slopes for the base run are twice the value suggested for Alaskan and Canadian BB pollution measured in the Azores in 2004, which yielded $\Delta \mathrm{O}_{3} / \Delta \mathrm{CO}$ enhancement ratios of 0.25 (Pfister et al., 2006). However, for the more reliable estimate using the FireCOSens run, the average slope of 0.26 is in very good agreement with prior work on aged Alaskan and Canadian BB plumes. We have also calculated the $\Delta \mathrm{O}_{3} / \Delta \mathrm{CO}$ slopes using the FireNOxSens run in place of the base model run (example plots shown in Fig. S11) and show the slopes of the $\Delta \mathrm{O}_{3} / \Delta \mathrm{CO}$ in Table 2 . The resulting average $\Delta \mathrm{O}_{3} / \Delta \mathrm{CO}$ slope is lower FireNOxSens $=0.20$. The reduction of $\mathrm{NO}_{\mathrm{x}}$ emissions from fires decreases the rate of ozone formation in fire plumes, resulting in less ozone in plumes and lower slopes. These values derived using the the FireNOxSens run are also more consistent with other studies for aged boreal forest fire plumes (e.g. values of 0.25 for BB plumes reported 

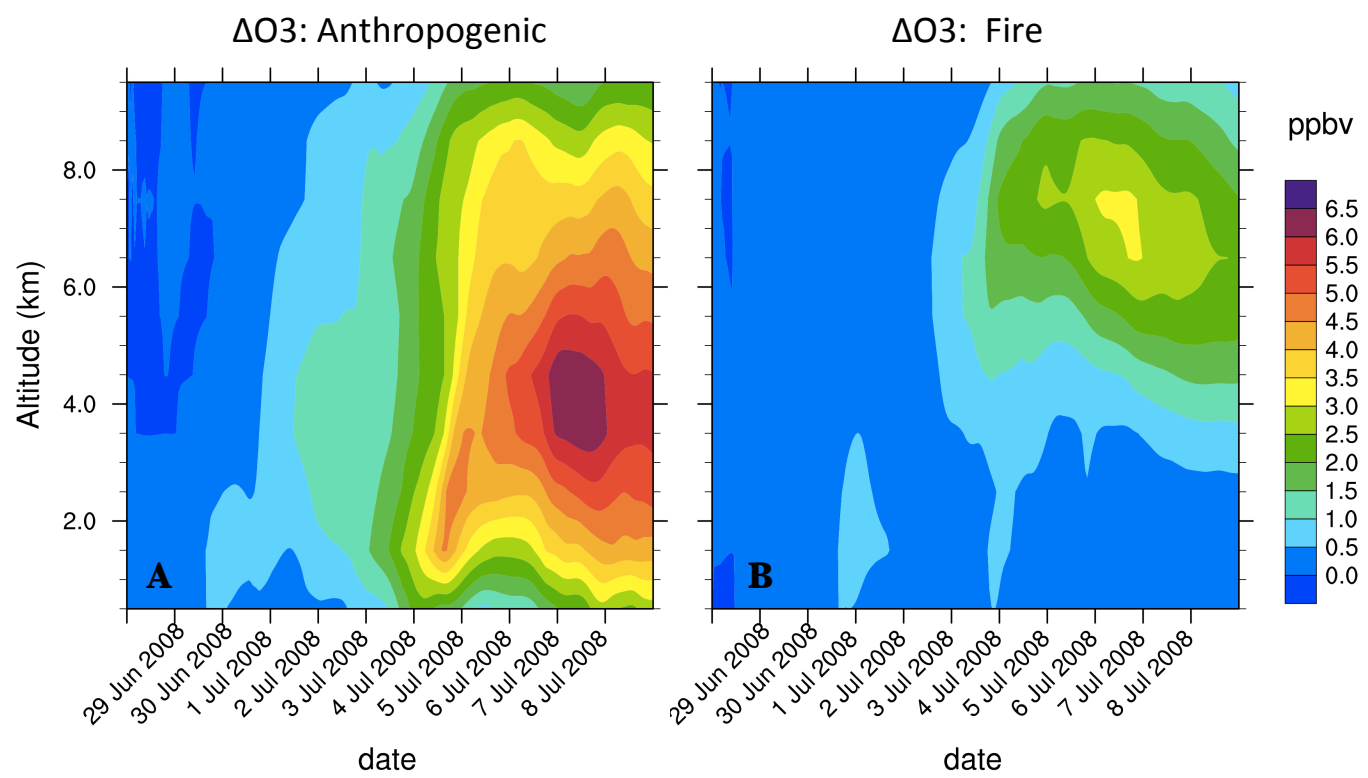

Fig. 13. The average increase in ozone $\left(\Delta \mathrm{O}_{3}\right)$ during the model run north of $55^{\circ} \mathrm{N}$ from anthropogenic plumes (a) and fire plumes (b). Excess ozone is calculated as the average ozone increase $\left(\Delta \mathrm{O}_{3}\right)$ north of $55^{\circ} \mathrm{N}$ upon including anthropogenic (base-noAnthro) or fire (base-noFire) emissions.

Table 2. Average slopes of best-fit lines for $\Delta \mathrm{O}_{3}$ as a function of $\Delta$ CO for 1 July-8 July 2008 (shown in Fig. 12). The distribution plots for the FireNOxSens run is shown in Fig. S11.

\begin{tabular}{lccc}
\hline Plume type & \multicolumn{3}{c}{ Slope: $\Delta \mathrm{O}_{3}(\mathrm{ppbv}) / \Delta \mathrm{CO}(\mathrm{ppbv})$} \\
\hline Fresh Anthropogenic & \multicolumn{3}{c}{0.63} \\
Aged Anthropogenic & \multicolumn{3}{c}{0.92} \\
\cline { 2 - 4 } & Base & FireCOSens & FireNOxSens \\
\cline { 2 - 4 } Fresh Fire & 0.08 & 0.07 & 0.07 \\
Aged Fire & 0.49 & 0.26 & 0.20 \\
\hline
\end{tabular}

by Pfister et al., 2006). In summary, the results demonstrate that the ozone enhancement ratios in aged plumes are very sensitive to both $\mathrm{CO}$ and $\mathrm{NO}_{\mathrm{x}}$ emissions from fires.

\subsection{Increase in ozone regionally due to pollution plumes}

In order to quantify the amount of ozone produced in pollution plumes and transported towards the Arctic during the study period (28 June-9 July), the increase in ozone due to anthropogenic and fire pollution $\left(\Delta \mathrm{O}_{3}\right)$ has been calculated as a function of altitude during the model run in the region lat $>55^{\circ} \mathrm{N}$ (shown in Fig. 13). Initially, ozone enhancements are zero because the runs use the same initial conditions. As the model run progresses, ozone enhancements increase as both fire and anthropogenic emissions are emitted within the model domain and transported towards the Arctic. At the end of the model run, ozone enhancements represent average increases in ozone due to accumulated emissions within the model domain. $\Delta \mathrm{O}_{3}$ due to anthropogenic pollution (Fig. 13a) has a peak of $6.5 \mathrm{ppbv}$ at $4 \mathrm{~km}$ (representing a maximum increase of $18 \%$ ). These increases in nearArctic ozone are significant considering the low background ozone mixing ratios in the Arctic. $\Delta \mathrm{O}_{3}$ due to $\mathrm{BB}$ pollution is lower than for anthropogenic emissions (Fig. 13b), consistent with the $\Delta \mathrm{O}_{3} / \Delta \mathrm{CO}$ analysis presented earlier. For fires, the largest $\Delta \mathrm{O}_{3}$ is $3 \mathrm{ppbv}$ (increase of $5.2 \%$ ) and peaks higher near $7 \mathrm{~km}$, showing fire pollution was transported to higher altitudes and is not always co-located with urban emissions. It is also important to note that the total amount of ozone formed in fire plumes is much less than from anthropogenic pollution during the model run in part because the total emissions from fires are lower. For example, BB CO emissions make up $21 \%$ of the total $\mathrm{CO}$ emissions during the base model run. These emissions sources also have differences in transport pathways, resulting in different amounts of ozone produced after transport.

\section{Conclusions}

We have used the regional model WRF-Chem to investigate the amount of ozone produced during transport towards the Arctic from Canadian boreal forest fires and North American anthropogenic emissions in summer 2008. Modeled concentrations were first evaluated using POLARCAT aircraft observations, including ARCTAS-B measurements of fresh Canadian forest fire plumes, MOZAIC data over the northeast United States, and POLARCAT-France/GRACE measurements of aged plumes over Greenland. 
In general, WRF-Chem simulations correctly represent the composition of fresh and aged BB plumes with some caveats. First, $\mathrm{CO}$ in fire plumes is too low using the FINNv1 emissions. A run with twice the fire $\mathrm{CO}$ emissions is in better agreement with the DC8 measurements of fresh BB emissions, an important conclusion regarding the $\mathrm{CO}$ emissions in the FINNv1 emissions inventory. In addition, NMHC concentrations are generally too low, while $\mathrm{NO}_{\mathrm{x}}$ levels are higher than measured. Agreement between the model and measurements for the POLARCAT flights downwind over Greenland is generally good, especially for ozone. For flights over the BB source region and downwind over Greenland, a run with additional $(2 \times) \mathrm{CO}$ emissions from fires is also in better agreement with measurements.

The model representation and origin of specific aged pollution plumes measured over Greenland onboard the ATR-42 aircraft are analyzed in detail. On 5 July, the aircraft measured a large anthropogenic pollution plume that extended from 3-7 km with both elevated ozone and CO. On 7 July, a BB plume that contained elevated $\mathrm{CO}$ and to some extent elevated ozone was encountered (vertical extent from 6-8 km). FLEXPART-WRF results were used to confirm the plume origins. Plumes were encountered near stratospheric air masses, which also contained elevated ozone. Using sensitivity runs without fire and anthropogenic emissions, we separated the contribution from pollution plumes and stratospheric air masses that remain when emissions are removed from the model. Analysis of the sensitivity runs shows that both anthropogenic and fire pollution contribute to the elevated $\mathrm{CO}$ and ozone observed during the flights over Greenland, with the majority of plumes analyzed consisting of either anthropogenic or BB pollution, rather than mixtures.

We also use differences between model runs with and without emissions to quantify the regional contribution of pollution to ozone levels. Over the northeastern United States and Canada, we derive moderate ozone enhancements (average $\Delta \mathrm{O}_{3} / \Delta \mathrm{CO}=0.63$ ) for fresh anthropogenic plumes. During transport, anthropogenic plumes continue to produce ozone with further enhanced $\Delta \mathrm{O}_{3} / \Delta \mathrm{CO}$ (average $=0.92$ ) after several days of transport. Near the source regions, little ozone production occurs in BB plumes as indicated by very low $\Delta \mathrm{O}_{3} / \Delta \mathrm{CO}$ values (average $=0.08$ ), consistent with earlier work on ozone production in BB plumes during ARCTAS-B. However, after transport and plume aging, $\Delta \mathrm{O} 3 / \Delta \mathrm{CO}$ values increase (average $=0.49$ for the base run, and $=0.26$ upon doubling $\mathrm{CO}$ emissions) for BB plumes, indicating significant ozone production occurred in these plumes further downwind. Sensitivity runs also show that $\Delta \mathrm{O}_{3} / \Delta \mathrm{CO}$ ratios are sensitive to the magnitude of emissions and an approximately linear decrease in aged plumes with either a doubling in fire $\mathrm{CO}$ emissions or reduction by a factor of two in fire $\mathrm{NO}_{\mathrm{x}}$ emissions.

The model results are used to quantify the amount of ozone produced from anthropogenic and fire emissions north of $55^{\circ} \mathrm{N}$. During the study period (29 June to 9 July 2008), an- thropogenic pollution from North America increases ozone by up to $6.5 \mathrm{ppbv}$ in the lower- to mid-troposphere and boreal fire pollution increases ozone by up to $3 \mathrm{ppbv}$ in the mid-/upper troposphere. Our study is based on a relatively short period of time, when there was active transport of both fire and anthropogenic plumes from North America to the east and north into the Arctic. However, our findings suggest a significant contribution to tropospheric ozone at higher latitudes from both anthropogenic and fire pollution transported toward the Arctic. These enhancements represent an increase in ozone of up to $18 \%$ from anthropogenic emissions (midtroposphere) and an increase of up to $5.2 \%$ from BB (upper troposphere). These increases cannot be disregarded considering the relatively low background ozone concentrations in the Arctic.

The results of this study indicate that fires in the boreal region may have a significant impact on ozone production, especially in the mid- and upper troposphere near the Arctic. We have focused on the wildfires in Canada during summer 2008, when a large coordinated set of aircraft campaigns (POLARCAT) occurred to specifically study the impact of fires on the Arctic. In contrast to published studies focusing mostly on very fresh fire emissions (ARCTAS-B), we show that Canadian fire plumes are photochemically active, producing ozone downwind after further aging.

Continued work to quantify the impact of pollution sources on Arctic ozone is needed. In this paper, we present results from a model run at sufficient spatial resolution to resolve pollution plumes allowing determination of ozone production in individual plumes. However, the contribution of boreal fire emissions to Arctic ozone regionally still remains uncertain. Additional work to compare regional and global models, including estimates of the amount of ozone produced in plumes will be necessary to better quantify the contribution of different pollution source regions to the Arctic ozone budget. Representation of the non-linear chemistry that occurs in plumes during long-range transport to the Arctic should be evaluated based on model runs at different resolutions and larger spatial domains and covering longer periods. Such studies can also be used to evaluate global chemistry-climate models which are often run at low spatial resolutions but which are the current tools used to make predictions about future atmospheric composition.

\section{Supplementary material related to this article is available online at: http://www.atmos-chem-phys.net/13/ 3825/2013/acp-13-3825-2013-supplement.pdf.}


Acknowledgements. We thank the POLARCAT aircraft teams especially the NASA ARCTAS, DLR-GRACE, and French ATR-42 teams. French ATR-42 campaigns and data analysis were part of POLARCAT-France funded by French Agence Nationale de la Recherche (ANR), CNES, CNRS-INSU-LEFE, IPEV and EUFAR. Authors (J. Thomas, K. Law and J. C. Raut) acknowledge support from projects ANR Climate Impact of Short-lived Climate Forcers and Methane in the Arctic (CLIMSLIP) Blanc SIMI 5-6 021 01, CLIMSLIP-LEFE (CNRS-INSU), and the European Union Arctic Climate Change, Economy and Society (ACCESS) project (FP7-SCP0-2011-265863). J. Fast was supported by the US Department of Energy (DOE) Office of Science (BER) Climate Change Modeling Program. We thank D. Blake and E. Apel (NMHC measurements) as well as Greg Huey (PAN measurements) and the entire ARCTAS team for the use of the measurements taken onboard the DC8. The authors acknowledge the strong support of the European Commission, Airbus, and the Airlines (Lufthansa, Austrian, Air France) who carry free of charge the MOZAIC equipment and perform the maintenance since 1994. MOZAIC is presently funded by INSU-CNRS (France), Meteo-France, and Forschungszentrum (FZJ, Julich, Germany). The MOZAIC database is supported by ETHER (CNES and INSU-CNRS). We also acknowledge valuable help from colleagues at PNNL, NCAR (C. Wiedinmyer, S. Walters) and LATMOS/IPSL (D. Cugnet and T. Onishi). The National Center for Atmospheric Research is operated by the University Corporation for Atmospheric Research with funding from the National Science Foundation. CNRS is acknowledged for publication cost support.

Edited by: P. Monks

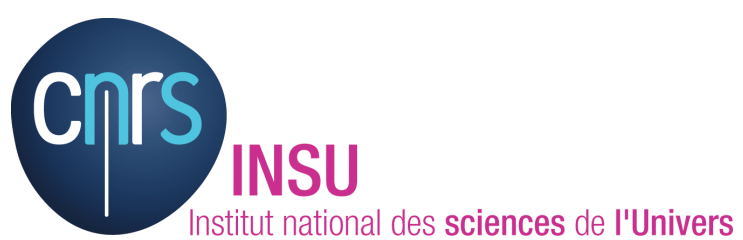

The publication of this article is financed by CNRS-INSU.

\section{References}

Abbatt, J. P. D., Thomas, J. L., Abrahamsson, K., Boxe, C., Granfors, A., Jones, A. E., King, M. D., Saiz-Lopez, A., Shepson, P. B., Sodeau, J., Toohey, D. W., Toubin, C., von Glasow, R., Wren, S. N., and Yang, X.: Halogen activation via interactions with environmental ice and snow in the polar lower troposphere and other regions, Atmos. Chem. Phys., 12, 6237-6271, doi:10.5194/acp-12-6237-2012, 2012.

Akagi, S. K., Yokelson, R. J., Wiedinmyer, C., Alvarado, M. J., Reid, J. S., Karl, T., Crounse, J. D., and Wennberg, P. O.: Emission factors for open and domestic biomass burning for use in atmospheric models, Atmos. Chem. Phys., 11, 4039-4072, doi:10.5194/acp-11-4039-2011, 2011.

Alvarado, M. J., Logan, J. A., Mao, J., Apel, E., Riemer, D., Blake, D., Cohen, R. C., Min, K.-E., Perring, A. E., Browne, E. C., Wooldridge, P. J., Diskin, G. S., Sachse, G. W., Fuelberg, H., Sessions, W. R., Harrigan, D. L., Huey, G., Liao, J.,
Case-Hanks, A., Jimenez, J. L., Cubison, M. J., Vay, S. A., Weinheimer, A. J., Knapp, D. J., Montzka, D. D., Flocke, F. M., Pollack, I. B., Wennberg, P. O., Kurten, A., Crounse, J., Clair, J. M. St., Wisthaler, A., Mikoviny, T., Yantosca, R. M., Carouge, C. C., and Le Sager, P.: Nitrogen oxides and PAN in plumes from boreal fires during ARCTAS-B and their impact on ozone: an integrated analysis of aircraft and satellite observations, Atmos. Chem. Phys., 10, 9739-9760, doi:10.5194/acp10-9739-2010, 2010.

Andreae, M. O. and Merlet, P.: Emission of trace gases and aerosols from biomass burning, Global Biogeochem. Cy., 15, 955-966, 2001.

Anisimov, O. A., Vaughan, D. G., Callaghan, T. V., Furgal, C., Marchant, H., Prowse, T. D., Vilhjalmsson, H., and Walksh, J. E.: Polar regions (Arctic and Antarctic), in: Climate Change 2007: Impacts, Adaptation, and Vulnerability. Contribution of Working Group II to the Fourth Assessment Report of the Intergovernmental Panel on Climate Change, edited by: Parry, M. L., Canziani, O. F., Palutikof, J. P., van der Linden, P. J., and Hanson, C. E., Cambridge University Press, Cambridge, 653-685, 2007.

Ancellet, G. and Ravetta, F.: Compact airborne lidar for tropospheric ozone: description and field measurements, Appl. Opt., 37, 5509-5521, 1998.

Ancellet, G. and Ravetta, F.: On the usefulness of an airborne lidar for $\mathrm{O}_{3}$ layer analysis in the free troposphere and the planetary boundary layer, J. Environ. Monitor., 5, 47-56, 2003.

Arctic Climate Impact Assessment: Impacts of a Warming Arctic: Arctic Climate Impact Assessment, Cambridge Univ. Press, New York, available at: http://www.cgrer.uiowa.edu/arctas/emission. html, 2004

Atlas, E. L., Ridley, B. A., and Cantrell, C.: Tropospheric Ozone Production about the Spring Equinox (TOPSE) Experiment: Introduction, J. Geophys. Res., 108, 8353, doi:10.1029/2002JD003172, 2003.

Barrie, L. A.: Arctic air pollution: an overview of current knowledge, Atmos. Environ., 20, 643-663, 1986.

Bian, H., Colarco, P., Chin, M., Chen, G., Douglass, A. R., Rodriguez, J. M., Liang, Q., Warner, J., Chu, D. A., Crounse, J., Cubison, M. J., da Silva, A., Dibb, J., Diskin, G., Fuelberg, H. E., Huey, G., Jimenez, J. L., Kondo, Y., Nielsen, J. E., Pawson, S., and Wei, Z.: Investigation of source attributions of pollution to the Western Arctic during the NASA ARCTAS field campaign, Atmos. Chem. Phys. Discuss., 12, 8823-8855, doi:10.5194/acpd-12-8823-2012, 2012.

Bottenheim, J. W., Barrie, L. A., Atlas, E., Heidt, L. E., Niki, H., Rasmussen, R. A., and Shepson, P. B.: Depletion of lower tropospheric ozone during Arctic spring - the Polar sunrise experiment 1988, J. Geophys. Res.-Atmos., 95, 18555-18568, 1990.

Chin, M., Ginoux, P., Kinne, S., Torres, O., Holben, B. N., Duncan, B. N., Martin, R. V., Logan, J. A., Higurashi, A., and Nakajima, T.: Tropospheric aerosol optical thickness from the GOCART model and comparisons with satellite and sunphotometer measurements, J. Atmos. Sci., 59, 461-483, 2002.

Comiso, J. C., Parkinson, C. L., Gersten, R., and Stock, L.: Accelerated decline in the Arctic sea ice cover, Geophys. Res. Lett., 35, L01703, doi:10.1029/2007GL031972, 2008.

Crutzen, P. J., Heidt, L. E., Krasnec, J. P., Pollock, W. H., and Seiler, W.: Biomass burning as a source of atmospheric gases 
$\mathrm{CO}, \mathrm{H}_{2}, \mathrm{~N}_{2} \mathrm{O}, \mathrm{NO}, \mathrm{CH}_{3} \mathrm{Cl}$ and COS, Nature, 282, 253-256, 1979.

Emmons, L. K., Hess, P., Klonecki, A., Tie, X., Horowitz, L., Lamarque, J.-F., Kinnison, D., Brasseur, G., Atlas, E., Browell, E., Cantrell, C., Eisele, F., Mauldin, R. L., Merrill, J., Ridley, B., and Shetter, R.: Budget of tropospheric ozone during TOPSE from two chemical transport models, J. Geophys. Res., 108, 8372, doi:10.1029/2002JD002665, 2003.

Emmons, L. K., Walters, S., Hess, P. G., Lamarque, J.-F., Pfister, G. G., Fillmore, D., Granier, C., Guenther, A., Kinnison, D., Laepple, T., Orlando, J., Tie, X., Tyndall, G., Wiedinmyer, C., Baughcum, S. L., and Kloster, S.: Description and evaluation of the Model for Ozone and Related chemical Tracers, version 4 (MOZART-4), Geosci. Model Dev., 3, 43-67, doi:10.5194/gmd3-43-2010, 2010.

Fan, S. M., Jacob, D. J., Mauzerall, D. L., Bradshaw, J. D., Sandholm, S. T., Blake, D. R., Singh, H. B., Talbot, R. W., Gregory, G. L., and Sachse, G. W.: Origin of thropospheric $\mathrm{NO}_{\mathrm{x}}$ over sub-Arctic Eastern Canada in summer, J. Geophys. Res., 99, 16867-16877, 1994.

Fast, J. D. and Easter, R. C.: A Lagrangian particle dispersion model compatible with WRF, in: 7th WRF User's Workshop, NCAR, P6-02, 19-22 June, Boulder, Colorado, 2006.

Fast, J. D., Gustafson Jr., W. W. I., Easter, R., Zaveri, R. A., Barnard, J. C., Chapman, E. G., Grell, G., and Peckham, S.: Evolution of ozone, particulates, and aerosol direct radiative forcing in the vicinity of Houston using a fully coupled meteorology-chemistry-aerosol model, J. Geophys. Res., 111, D21305, doi:10.1029/2005JD006721, 2006.

Fast, J. D., Gustafson Jr., W. I., Chapman E. G., Easter R. C., Rishel J., Zaveri R. A., Grell G., and Barth, M.: The aerosol modeling testbed: a community tool to objectively evaluate aerosol process modules, B. Am. Meteorol. Soc., 92, 343-360, 2011.

Fisher, J. A., Jacob, D. J., Purdy, M. T., Kopacz, M., Le Sager, P., Carouge, C., Holmes, C. D., Yantosca, R. M., Batchelor, R. L., Strong, K., Diskin, G. S., Fuelberg, H. E., Holloway, J. S., Hyer, E. J., McMillan, W. W., Warner, J., Streets, D. G., Zhang, Q., Wang, Y., and Wu, S.: Source attribution and interannual variability of Arctic pollution in spring constrained by aircraft (ARCTAS, ARCPAC) and satellite (AIRS) observations of carbon monoxide, Atmos. Chem. Phys., 10, 977-996, doi:10.5194/acp-10-977-2010, 2010.

Freitas, S. R., Longo, K. M., Chatfield, R., Latham, D., Silva Dias, M. A. F., Andreae, M. O., Prins, E., Santos, J. C., Gielow, R., and Carvalho Jr., J. A.: Including the sub-grid scale plume rise of vegetation fires in low resolution atmospheric transport models, Atmos. Chem. Phys., 7, 3385-3398, doi:10.5194/acp-7-3385-2007, 2007.

Fuelberg, H. E., Harrigan, D. L., and Sessions, W.: A meteorological overview of the ARCTAS 2008 mission, Atmos. Chem. Phys., 10, 817-842, doi:10.5194/acp-10-817-2010, 2010.

Gerbig, C., Schmitgen, S., Kley, D., Volz-Thomas, A., Dewey, K., and Haaks, D.: An improved fast-response vacuum-UV resonance fluorescence CO instrument, J. Geophys. Res., 104, 16991704, 1999.

Grell, G. A., Peckham, S. E., Schmitz, R., McKeen, S. A., Frost, G., Skamarock, W. C., and Eder, B.: Fully coupled "online" chemistry within the WRF model, Atmos. Environ., 39, 6957-6975, 2005.
Guenther, A., Karl, T., Harley, P., Wiedinmyer, C., Palmer, P. I., and Geron, C.: Estimates of global terrestrial isoprene emissions using MEGAN (Model of Emissions of Gases and Aerosols from Nature), Atmos. Chem. Phys., 6, 3181-3210, doi:10.5194/acp-63181-2006, 2006.

Hecobian, A., Liu, Z., Hennigan, C. J., Huey, L. G., Jimenez, J. L., Cubison, M. J., Vay, S., Diskin, G. S., Sachse, G. W., Wisthaler, A., Mikoviny, T., Weinheimer, A. J., Liao, J., Knapp, D. J., Wennberg, P. O., Kürten, A., Crounse, J. D., Clair, J. St., Wang, Y., and Weber, R. J.: Comparison of chemical characteristics of 495 biomass burning plumes intercepted by the NASA DC- 8 aircraft during the ARCTAS/CARB2008 field campaign, Atmos. Chem. Phys., 11, 13325-13337, doi:10.5194/acp-11-13325-2011, 2011.

Hornbrook, R. S., Blake, D. R., Diskin, G. S., Fried, A., Fuelberg, H. E., Meinardi, S., Mikoviny, T., Richter, D., Sachse, G. W., Vay, S. A., Walega, J., Weibring, P., Weinheimer, A. J., Wiedinmyer, C., Wisthaler, A., Hills, A., Riemer, D. D., and Apel, E. C.: Observations of nonmethane organic compounds during ARCTAS -; Part 1: Biomass burning emissions and plume enhancements, Atmos. Chem. Phys., 11, 11103-11130, doi:10.5194/acp-11-11103-2011, 2011.

HTAP: Hemispheric transport of air pollution 2010, part A: ozone and particulate matter, in: Air Pollution Studies No. 17, edited by: Dentener, F., Keating, T., and Akimoto, H., United Nations, New York and Geneva, 2010.

IPCC, Core Writing Team, Pachauri, R. K., and Reisinger, A. (Eds.): Contribution of Working Groups I, II and III to the Fourth Assessment Report of the Intergovernmental Panel on Climate Change, IPCC, Geneva, Switzerland, 2007.

Jacob, D. J., Wofsy, S. C., Bakwin, P. S., Fan, S.-M., Harriss, R. C., Talbot, R. W., Bradshaw, J., Sandholm, S., Singh, H. B., Gregory, G. L., Browell, E. V., Sachse, G. W., Blake, D. R., and Fitzjarrald, D. R.: Summertime photochemistry at high northern latitudes, J. Geophys. Res., 97, 16421-16431, 1992.

Jacob, D. J., Crawford, J. H., Maring, H., Clarke, A. D., Dibb, J. E., Emmons, L. K., Ferrare, R. A., Hostetler, C. A., Russell, P. B., Singh, H. B., Thompson, A. M., Shaw, G. E., McCauley, E., Pederson, J. R., and Fisher, J. A.: The Arctic Research of the Composition of the Troposphere from Aircraft and Satellites (ARCTAS) mission: design, execution, and first results, Atmos. Chem. Phys., 10, 5191-5212, doi:10.5194/acp-10-5191-2010, 2010.

Jaffe, D. A. and Wigder, N. L.: Ozone production from wildfires: a critical review, Atmos. Environ., 51, 1-10, doi:10.1016/j.atmosenv.2011.11.063, 2012.

Jaffe, D., Anderson, T., Covert, D., Trost, B., Danielson, J., Simpson, W., Blake, D., Harris, J., and Streets, D.: Observations of ozone and related species in the Northeast Pacific during the PHOBEA campaigns: 1. ground based observations at Cheeka Peak. J. Geophys. Res., 106, 7449-7461, 2001.

Jaffe, D., Bertschi, I., Jaegle, L., Novelli, P., Reid, J. S., Tanimoto, H., Vingarzan, R., and Westphal, D. L.: Long-range transport of Siberian biomass burning emissions and impact on surface ozone in Western North America, Geophys. Res. Lett., 31, L16106, doi:10.1029/2004GL020093, 2004.

Koch, D., Bauer, S. E., Del Genio, A. D., Faluvegi, G., McConnell, J. R., Menon, S., Miller, R. L., Rind, D., Ruedy, R., Schmidt, G. A., and Shindell, D.: Coupled aerosol-chemistryclimate twentieth-century transient model investigation: trends 
in short-lived species and climate response, J. Climate, 24, 26932714, doi:10.1175/2011JCLI3582.1, 2011.

Law, K. S. and Stohl, A.: Arctic air pollution: origins and impacts, Science, 315, 1537-1540, 2007.

Liang, Q., Rodriguez, J. M., Douglass, A. R., Crawford, J. H., Olson, J. R., Apel, E., Bian, H., Blake, D. R., Brune, W., Chin, M., Colarco, P. R., da Silva, A., Diskin, G. S., Duncan, B. N., Huey, L. G., Knapp, D. J., Montzka, D. D., Nielsen, J. E., Pawson, S., Riemer, D. D., Weinheimer, A. J., and Wisthaler, A.: Reactive nitrogen, ozone and ozone production in the Arctic troposphere and the impact of stratosphere-troposphere exchange, Atmos. Chem. Phys., 11, 13181-13199, doi:10.5194/acp-1113181-2011, 2011.

Lobert, J. M. and Warnatz, J.: Emissions from the combustion process in vegetation, in: Fire in the Environment: the Ecological, Atmospheric, and Climatic Importance of Vegetation Fires, edited by: Crutzen, P. J. and Goldammer, J. G., John Wiley, New York, USA, 15-37, 1993.

Marenco, A., Thouret, V., Nédélec, P., Smit, H., Helten, M., Kley, D., Karcher, F., Simon, P., Law, K., Pyle, J., Poschmann, G., Von Wrede, R., Hume, C., and Cook, T.: Measurement of ozone and water vapor by Airbus in-service aircraft: the MOZAIC airborne program, an overview, J. Geophys. Res., 103, 25631-25642, 1998.

Mauzerall, D. L., Jacob, D. J., Fan, S.-M., Bradshaw, J. D., Gregory, G. L., Sachse, G. W., and Blake, D. R.: Origin of tropospheric ozone at remote high northern latitudes in summer, J. Geophys. Res., 101, 4175-4188, 1996.

Mauzerall, D. L., Logan, J. A., Jacob, D. J., Anderson, B. E., Blake, D. R., Bradshaw, J. D., Heikes, B., Sachse, G. W., Singh, H., and Talbot, B.: Photochemistry in biomass burning plumes and implications for tropospheric ozone over the tropical South Atlantic, J. Geophys. Res.-Atmos., 103, 8401-8423, 1998.

McKeen, S. A., Wotawa, G., Parrish, D. D., Holloway, J. S., Buhr, M. P., Hubler, G., Fehsenfeld, F. C., and Meagher, J. F.: Ozone production from Canadian wildfires during June and July of 1995, J. Geophys. Res., 107, 4192, doi:10.1029/2001JD000697, 2002.

Nédéléc, P., Cammas, J.-P., Thouret, V., Athier, G., Cousin, J.-M., Legrand, C., Abonnel, C., Lecoeur, F., Cayez, G., and Marizy, C.: An improved infrared carbon monoxide analyser for routine measurements aboard commercial Airbus aircraft: technical validation and first scientific results of the MOZAIC III programme, Atmos. Chem. Phys., 3, 1551-1564, doi:10.5194/acp-3-15512003, 2003.

Olson, J. R., Crawford, J. H., Brune, W., Mao, J., Ren, X., Fried, A., Anderson, B., Apel, E., Beaver, M., Blake, D., Chen, G., Crounse, J., Dibb, J., Diskin, G., Hall, S. R., Huey, L. G., Knapp, D., Richter, D., Riemer, D., Clair, J. St., Ullmann, K., Walega, J., Weibring, P., Weinheimer, A., Wennberg, P., and Wisthaler, A.: An analysis of fast photochemistry over high northern latitudes during spring and summer using in-situ observations from ARCTAS and TOPSE, Atmos. Chem. Phys., 12, 6799-6825, doi:10.5194/acp-12-6799-2012, 2012.

Oltmans, S. J., Lefohn, A. S., Harris, J. M., Tarasick, D. W., Thompson, A. M., Wernli, H., Johnson, B. J., Novelli, P. C., Montzka, S. A., Ray, J. D., Patrick, L. C., Sweeney, C., Jefferson, A., Dann, T., Davies, J., Shapiro, M., and Holben, B. N.: Enhanced ozone over Western North America from biomass burn- ing in Eurasia during April 2008 as seen in surface and profile observations, Atmos. Environ., 44, 4497-4509, 2010.

Parrington, M., Palmer, P. I., Henze, D. K., Tarasick, D. W., Hyer, E. J., Owen, R. C., Helmig, D., Clerbaux, C., Bowman, K. W., Deeter, M. N., Barratt, E. M., Coheur, P.-F., Hurtmans, D., Jiang, Z., George, M., and Worden, J. R.: The influence of boreal biomass burning emissions on the distribution of tropospheric ozone over North America and the North Atlantic during 2010, Atmos. Chem. Phys., 12, 2077-2098, doi:10.5194/acp-122077-2012, 2012.

Parrish, D. D., Holloway, J. S., Trainer, M., Murphy, P. C., Forbes, G. L., and Fehsenfeld, F. C.: Export of North American ozone pollution to the North Atlantic Ocean, Science, 259, 1436-1439, 1993.

Parrish, D. D., Law, K. S., Staehelin, J., Derwent, R., Cooper, O. R., Tanimoto, H., Volz-Thomas, A., Gilge, S., Scheel, H.-E., Steinbacher, M., and Chan, E.: Long-term changes in lower tropospheric baseline ozone concentrations at northern mid-latitudes, Atmos. Chem. Phys., 12, 11485-11504, doi:10.5194/acp-1211485-2012, 2012.

Peffers, L. T., Fuelberg, H. E., and Rao, P. A.: Evaluation of smoke plume dispersion in complex terrain using a Lagrangian particle dispersion model driven by WRF output, 11th Conf. Atmos. Chemistry, Amer. Meteor. Soc., Phoenix, Paper 3.6, 2009.

Pfister, G., Emmons, L. K., Hess, P. G., Honrath, R., Lamarque, J.-F., Val Martin, M., Owen, R. C., Avery, M., Browell, E. V., Holloway, J. S., Nedelec, P., Purvis, R., Rywerson, T. B., Sachse, G. W., and Schlager, H.: Ozone production from the 2004 North American boreal fires, J. Geophys. Res., 111, D24S07, doi:10.1029/2006JD007695, 2006.

Pfister, G. G., Wiedinmyer, C., and Emmons, L. K.: Impacts of the fall 2007 California wildfires on surface ozone: integrating local observations with global model simulations, Geophys. Res. Lett., 35, L19814, doi:10.1029/2008GL034747, 2008.

Pfister, G. G., Avise, J., Wiedinmyer, C., Edwards, D. P., Emmons, L. K., Diskin, G. D., Podolske, J., and Wisthaler, A.: CO source contribution analysis for California during ARCTASCARB, Atmos. Chem. Phys., 11, 7515-7532, doi:10.5194/acp11-7515-2011, 2011.

Pommier, M., Law, K. S., Clerbaux, C., Turquety, S., Hurtmans, D., Hadji-Lazaro, J., Coheur, P.-F., Schlager, H., Ancellet, G., Paris, J.-D., Nédélec, P., Diskin, G. S., Podolske, J. R., Holloway, J. S., and Bernath, P.: IASI carbon monoxide validation over the Arctic during POLARCAT spring and summer campaigns, Atmos. Chem. Phys., 10, 10655-10678, doi:10.5194/acp-10-10655-2010, 2010.

Pommier, M., Clerbaux, C., Law, K. S., Ancellet, G., Bernath, P., Coheur, P.-F., Hadji-Lazaro, J., Hurtmans, D., Nédélec, P., Paris, J.-D., Ravetta, F., Ryerson, T. B., Schlager, H., and Weinheimer, A. J.: Analysis of IASI tropospheric $\mathrm{O}_{3}$ data over the Arctic during POLARCAT campaigns in 2008, Atmos. Chem. Phys., 12, 7371-7389, doi:10.5194/acp-12-7371-2012, 2012.

Post, E., Forchhammer, M. C., Bret-Harte, M. S., Callaghan, T. V., Christensen, T. R., Elberling, B., Fox, A. D., Gilg, O., Hik, D. S., Høye, T. T., Ims, R. A., Jeppesen, E., Klein, D. R., Madsen, J., McGuire, A. D., Rysgaard, S., Schindler, D. E., Stirling, I., Tamstorf, M. P., Tyler, N. J., van der Wal, R., Welker, J., Wookey, P. A., Schmidt, N. M., and Aastrup, P.: Ecological dynamics across the arctic associated with recent climate change, 
Science, 325, 1355-1358, doi:10.1126/science.1173113, 2009.

Quinn, P. K., Bates, T. S., Baum, E., Doubleday, N., Fiore, A. M., Flanner, M., Fridlind, A., Garrett, T. J., Koch, D., Menon, S., Shindell, D., Stohl, A., and Warren, S. G.: Short-lived pollutants in the Arctic: their climate impact and possible mitigation strategies, Atmos. Chem. Phys., 8, 1723-1735, doi:10.5194/acp8-1723-2008, 2008.

Real, E., Law, K. S., Weinzierl, B., Fiebig, M., Petzold, A., Wild, O., Methven, J., Arnold, S., Stohl, A., Huntrieser, H., Roiger, A., Schlager, H., Stewart, D., Avery, M., Sachse, G., Browell, E., Ferrare, R., and Blake, D.: Processes influencing ozone levels in Alaskan forest fire plumes during long-range transport over the North Atlantic, J. Geophys. Res., 112, D10S41, doi:10.1029/2006JD007576, 2007.

Reid, J., Hyer, E., Prins, E., Westphal, D. L., Zhang, J., Wang, J., Christopher, S., Curtis, C., Schmidt, C., Eleuterio, D., Richardson, K., and Hoffman, J.: Global monitoring and forecasting of biomass-burning smoke: description of and lessons from the Fire Locating and Modeling of Burning Emissions (FLAMBE) program, IEEE, J. Appl. Earth Observ. Remote Sens., 2, 144-161, 2009.

Roiger, A., Aufmhoff, H., Stock, P., Arnold, F., and Schlager, H.: An aircraft-borne chemical ionization - ion trap mass spectrometer (CI-ITMS) for fast PAN and PPN measurements, Atmos. Meas. Tech., 4, 173-188, doi:10.5194/amt-4-173-2011, 2011a.

Roiger, A., Schlager, H., Schäfler, A., Huntrieser, H., Scheibe, M., Aufmhoff, H., Cooper, O. R., Sodemann, H., Stohl, A., Burkhart, J., Lazzara, M., Schiller, C., Law, K. S., and Arnold, F.: In-situ observation of Asian pollution transported into the Arctic lowermost stratosphere, Atmos. Chem. Phys., 11, 10975-10994, doi:10.5194/acp-11-10975-2011, 2011b.

Sachse, G. W., Hill, G. F., Wade, L. O., and Perry, M. G.: Fastresponse, high-precision carbon monoxide sensor using a tunable diode laser absorption technique, J. Geophys. Res., 92, 20712081, 1987.

Schmale, J., Schneider, J., Ancellet, G., Quennehen, B., Stohl, A., Sodemann, H., Burkhart, J. F., Hamburger, T., Arnold, S. R., Schwarzenboeck, A., Borrmann, S., and Law, K. S.: Source identification and airborne chemical characterisation of aerosol pollution from long-range transport over Greenland during POLARCAT summer campaign 2008, Atmos. Chem. Phys., 11, 1009710123, doi:10.5194/acp-11-10097-2011, 2011.

Sessions, W. R., Fuelberg, H. E., Kahn, R. A., and Winker, D. M.: An investigation of methods for injecting emissions from boreal wildfires using WRF-Chem during ARCTAS, Atmos. Chem. Phys., 11, 5719-5744, doi:10.5194/acp-11-5719-2011, 2011.

Shindell, D.: Local and remote contributions to Arctic warming, Geophys. Res. Lett., 34, L14704, doi:10.1029/2007GL030221, 2007.

Shindell, D. T., Chin, M., Dentener, F., Doherty, R. M., Faluvegi, G., Fiore, A. M., Hess, P., Koch, D. M., MacKenzie, I. A., Sanderson, M. G., Schultz, M. G., Schulz, M., Stevenson, D. S., Teich, H., Textor, C., Wild, O., Bergmann, D. J., Bey, I., Bian, H., Cuvelier, C., Duncan, B. N., Folberth, G., Horowitz, L. W., Jonson, J., Kaminski, J. W., Marmer, E., Park, R., Pringle, K. J., Schroeder, S., Szopa, S., Takemura, T., Zeng, G., Keating, T. J., and Zuber, A.: A multi-model assessment of pollution transport to the Arctic, Atmos. Chem. Phys., 8, 5353-5372, doi:10.5194/acp-8-5353-2008, 2008.
Simpson, W. R., von Glasow, R., Riedel, K., Anderson, P., Ariya, P., Bottenheim, J., Burrows, J., Carpenter, L. J., Frieß, U., Goodsite, M. E., Heard, D., Hutterli, M., Jacobi, H.-W., Kaleschke, L., Neff, B., Plane, J., Platt, U., Richter, A., Roscoe, H., Sander, R., Shepson, P., Sodeau, J., Steffen, A., Wagner, T., and Wolff, E.: Halogens and their role in polar boundary-layer ozone depletion, Atmos. Chem. Phys., 7, 4375-4418, doi:10.5194/acp-7-43752007, 2007.

Singh, H., Viezee, W., Chen, Y., Bradshaw, J., Sandholm, S., Blake, D., Blake, N., Heikes, B., Snow, J., Talbot, R., Browell, E., Gregory, G., Sachse, G., and Vay, S.: Biomass burning influences on the composition of the remote South Pacific troposphere: analysis based on observations from PEM-Tropics-A, Atmos. Env., 34, 635-644, 2000.

Singh, H. B., Anderson, B. E., Brune, W. H., Cai, C., Cohen, R. C., Crawford, J. H., Cubison, M. J., Czech, E. P., Emmons, L., Fuelberg, H. E., Huey, G., Jacob, D. J., Jimenez, J. L., Kaduwela, A., Kondo, Y., Mao, J., Olson, J. R., Sachse, G. W., Vay, S. A., Weinheimer, A., Wennberg, P. O., and Wisthaler, A.: Pollution influences on atmospheric composition and chemistry at high northern latitudes: boreal and California forest fire emissions, Atmos. Environ., 44, 4553-4563, doi:10.1016/j.atmosenv.2010.08.026, 2010.

Stohl, A., Forster, C., Frank, A., Seibert, P., and Wotawa, G.: Technical note: The Lagrangian particle dispersion model FLEXPART version 6.2, Atmos. Chem. Phys., 5, 2461-2474, doi:10.5194/acp-5-2461-2005, 2005.

Thouret, V., Marenco, A., Logan, J. A., Nédélec, P., and Grouhel, C.: Comparisons of ozone measurements from the MOZAIC airborne program and the ozone sounding network at eight locations, J. Geophys. Res., 103, 25695-25720, 1998.

Tilmes, S., Emmons, L. K., Law, K. S., Ancellet, G., Schlager, H., Paris, J.-D., Fuelberg, H. E., Streets, D. G., Wiedinmyer, C., Diskin, G. S., Kondo, Y., Holloway, J., Schwarz, J. P., Spackman, J. R., Campos, T., Nédélec, P., and Panchenko, M. V.: Source contributions to Northern Hemisphere CO and black carbon during spring and summer 2008 from POLARCAT and START08/preHIPPO observations and MOZART-4, Atmos. Chem. Phys. Discuss., 11, 5935-5983, doi:10.5194/acpd-115935-2011, 2011.

Val Martin, M., Honrath, R. E., Owen, R. C., Lapina, K.: Large-scale impacts of anthropogenic pollution and boreal wildfires on the nitrogen oxides over the Central North Atlantic region, J. Geophys. Res.-Atmos., 113, D17308, doi:10.1029/2007JD009689, 2008.

Vay, S. A., Anderson, B. E., Sachse, G. W., Collins Jr., J., E., Podolske, J. R., Twohy, C. H., Gandrud, B., Chan, K. R., Baughcum, S. L., and Wallio. H. A.: DC-8 observations of aircraft CO, $\mathrm{CH}_{4}, \mathrm{~N}_{2} \mathrm{O}$, and $\mathrm{H}_{2} \mathrm{O}_{\mathrm{g}}$ emission indices during SUCCESS, Geophys. Res. Lett., 25, 1717-1720, 1998.

Walker, T. W., Jones, D. B. A., Parrington, M., Henze, D. K., Murray, L. T., Bottenheim, J. W., Anlauf, K., Worden, J. R., Bowman, K. W., Shim, C., Singh, K., Kopacz, M., Tarasick, D. W., Davies, J., von der Gathen, P., Thompson, A. M., Carouge, C. C.: Impacts of midlatitude precursor emissions and local photochemistry on ozone abundances in the Arctic. J. Geophys. Res., 117, D01305, doi:10.1029/2011JD016370, 2012.

Weinheimer, A. J., Walega, J. G., Ridley, B. A., Gary, B. L., Blake, D. R., Blake, N. J., Rowland, F. S., Sachse, G. W., 
Anderson, B. E., and Collins, J. E.: Meridional distributions of $\mathrm{NO}_{\mathrm{x}}, \mathrm{NO}_{\mathrm{y}}$, and other species in the lower stratosphere and upper troposphere during AASE II, Geophys. Res. Lett., 21, 25832586, 1994.

Wespes, C., Emmons, L., Edwards, D. P., Hannigan, J., Hurtmans, D., Saunois, M., Coheur, P.-F., Clerbaux, C., Coffey, M. T., Batchelor, R. L., Lindenmaier, R., Strong, K., Weinheimer, A. J., Nowak, J. B., Ryerson, T. B., Crounse, J. D., and Wennberg, P. O.: Analysis of ozone and nitric acid in spring and summer Arctic pollution using aircraft, ground-based, satellite observations and MOZART-4 model: source attribution and partitioning, Atmos. Chem. Phys., 12, 237-259, doi:10.5194/acp12-237-2012, 2012.

Wiedinmyer, C., Quayle, B., Geron, C., Belote, A., McKenzie, D., Zhang, X., O’Neill, S., Klos, K., and Wynne, K. K.: Estimating emissions from fires in North America for air quality modelling, Atmos. Environ., 40, 3419-3432, 2006.

Wiedinmyer, C., Akagi, S. K., Yokelson, R. J., Emmons, L. K., AlSaadi, J. A., Orlando, J. J., and Soja, A. J.: The Fire INventory from NCAR (FINN): a high resolution global model to estimate the emissions from open burning, Geosci. Model Dev., 4, 625641, doi:10.5194/gmd-4-625-2011, 2011.
Wild, O., Law, K. S., McKenna, D. S., Bandy, B. J., Penkett, S. A., and Pyle, J. A.: Photochemical trajectory modeling studies of the North Atlantic region during August 1993, J. Geophys. Res., 101, 269-29, doi:10.1029/96JD00837, 1996.

WMO/UNEP, Integrated Assessment of Black Carbon and Tropospheric Ozone, UNON/Publishing Services Section, UNON/Publishing Services Section, Nairobi, 2011.

Wofsy, S. C., Sachse, G. W., Gregory, G. L., Blake, D. R., Bradshaw, J. D., Sandholm, S. T., Singh, H. B., Barrick, J. A., Harriss, R. C., Talbot, R. W., Shipham, M. A., Browell, E. V., Jacob, D. J., and Logan. J. A.: Atmospheric chemistry in the arctic and subarctic: influence of natural fires, industrial emissions, and stratospheric inputs, J. Geophys. Res., 97, 16731-16746, 1992.

Ziereis, H., Schlager, H., Schulte, P., van Velthoven, P., and Slemr, F.: Distributions of $\mathrm{NO}, \mathrm{NO}_{\mathrm{x}}$, and $\mathrm{NO}_{\mathrm{y}}$ in the upper troposphere and lower stratosphere between $28^{\circ}$ and $61^{\circ} \mathrm{N}$ during POLINAT 2, J. Geophys. Res., 105, doi:10.1029/1999JD900870, 3653, 2000. 